\title{
PENGARUH PENYALURAN DANA DESA PADA INDIKATOR PEREKONOMIAN KABUPATEN DAERAH TERTINGGAL DI INDONESIA
}

\author{
Gema Otheliansyah \\ PKN STAN \\ Raynal Yasni \\ PKN STAN \\ Alamat Korepondensi: gemaothe@gmail.com
}

\begin{abstract}
The different characteristics of each region in Indonesia cause dissimilarity pattern of the development economic, the infrastructure and the human resources. Thus, factors lead to the inequality problem. Some regions grow massively but on the other side there are some regions that grow slowly, or we called them as underdeveloped areas. To overcome that problem, the central government instructs to focus on developing rural areas and underdeveloped areas. Those kind of areas are still considered lagging behind, both in economic and development aspects. Rural Area Regulation assigns government to distribute "Rural Area Funds" which is expected to be the solution of that slowly growth problem. The purpose of this research is to determine the effect of Rural Area Funds (Dana Desa) distribution to two economic indicators in 122 underdeveloped areas. The analytical method uses simultaneous equation model which consists of two structural equations. The results showed that the distribution of rural Area funds had an impact on two economic indicators of underdeveloped areas.
\end{abstract}

\begin{abstract}
ABSTRAK
Perbedaaan karakteristik di setiap wilayah di Indonesia mengakibatkan pola pembangunan ekonomi infrastruktur dan sumber daya manusia di tiap daerah menjadi tidak seragam. Hal tersebut berimplikasi pada munculnya masalah ketimpangan. Ada daerah yang maju lebih cepat dan ada juga daerah yang tumbuh lebih lambat atau bisa dikatakan sebagai daerah tertinggal. Untuk mengatasi permasalahan tersebut, pemerintah pusat mengarahkan kegiatan pembangunan di daerah dengan fokus utama desa dan daerah tertinggal. Daerah tertinggal dianggap masih tertinggal di berbagai aspek ekonomi dan pembangunan. Undang-Undang Desa memberikan mandat kepada pemerintah pusat untuk menyalurkan Dana Desa, yang diharapkan dapat menjadi solusi untuk permasalahan tersebut. Tujuan penilitian ini ialah untuk mengetahui pengaruh penyaluran Dana Desa terhadap dua indikator perekonomian pada 122 kabupaten daerah tertinggal. Metode analisis yang digunakan ialah model persamaan simultan dengan dua persamaan struktural. Hasil penelitian menunjukkan bahwa penyaluran dana desa memberikan pengaruh bagi dua indikator perekonomian daerah tertinggal.
\end{abstract}

KATA KUNCI:

Daerah Tertinggal, Dana Desa, Kemiskinan, PDRB per Kapita

\section{KLASIFIKASI JEL:}

I38

\section{CARA MENGUTIP:}

Otheliansyah, G. \& Yasni, R. (2021). Pengaruh penyaluran dana desa pada indikator perekonomian kabupaten daerah tertinggal di Indonesia. Indonesian Treasury Review: Jurnal Perbendaharaan, Keuangan Negara dan Kebijakan Publik, 6(1), 57-74. 


\section{PENDAHULUAN}

\subsection{Latar Belakang}

Perbedaaan karakteristik setiap wilayah di Indonesia mengakibatkan pola kegiatan ekonomi dan pola pembangunan infrastruktur dan sumber daya manusia di tiap daerah menjadi tidak seragam (Bappenas 2016). Hal tersebut berimplikasi pada munculnya masalah kesenjangan/ketimpangan dalam berbagai hal. Ada daerah yang maju lebih cepat dan ada juga daerah yang pertumbuhannya lebih lambat atau disebut daerah tertinggal.

Berbagai bentuk transfer fiskal telah disalurkan pemerintah pusat dalam rangka pelaksanaan desentralisasi fiskal. Akan tetapi, transfer fiskal tersebut cenderung menguntungkan masyarakat sektor non pertanian dibandingkan masyarakat sektor pertanian yang mayoritas tinggal di pedesaan (Nanga 2006). Hal tersebut mengindikasikan bahwa tingkat ekonomi dan kemiskinan di desa menjadi semakin memburuk setelah penerapan desentralisasi fiskal.

Untuk mengatasi permasalahan tersebut, dalam RPJMN (Rencana Pembangunan Jangka Menengah Nasional) 2015-2019 pemerintah pusat mengarahkan kegiatan pembangunan di daerah pedesaan dan daerah tertinggal. Desa dan daerah tertinggal dianggap masih tertinggal di berbagai aspek ekonomi dan pembangunan jika dibandingkan dengan daerah perkotaan. Hal tersebut merupakan akibat dari pembangunan ekonomi di masa lalu yang cenderung fokus perkotaan (urban bias). Kondisi ini memicu banyaknya arus urbanisasi, yang turut serta menimbulkan berbagai masalah sosial dan ekonomi di perkotaan. Salah satu rekomendasi Bappenas (2017) ialah pembangunan desa dan daerah tertinggal harus lebih diutamakan guna memutus rantai ketimpangan ekonomi dan pembangunan, terutama antara desa dan daerah tertinggal dengan perkotaan.

Menurut De Janvry dan Sadoulet (2010), dua strategi yang dilakukan untuk menanggulangi kemiskinan, yaitu: (i) transfer pendapatan (cash transfer) dan, (ii) transfer dana untuk pembangunan yang memihak pertumbuhan penduduk miskin (pro-poor growth). Kebijakan transfer pendapatan memberikan efek lebih cepat dan berdampak secara langsung pada pertumbuhan ekonomi, dikarenakan, transfer pendapatan dapat meningkatan pendapatan penduduk secara individu. Ada beberapa kebijakan transfer pendapatan yang pernah dijalankan oleh pemerintah Indonesia, antara lain: program belanja bantuan sosial kepada masyarakat miskin terdampak dalam bentuk bantuan langsung tunai, dan beras untuk keluarga miskin.

Strategi pro-poor growth memberikan dianggap memberikan pengaruh tidak langsung, yaitu pengaruh pada peningkatan pendapatan penduduk miskin melalui efek multiplier dari pertumbuhan ekonomi yang terjadi. Efek multiplier dari pertumbuhan ekonomi akan berdampak pada pengurangan tingkat kemiskinan dan ketimpangan pendapatan di masyarakat (Kakwani dan Pernia 2000).

Mulai tahun 2015, Pemerintahan Presiden Jokowi melaksanakan program transfer yang bersifat pro-poor growth berupa penyaluran langsung Dana Desa. Namun dalam terminologi postur APBN, Dana Desa tidak termasuk dalam kategori dana transfer, melainkan dikategorikan tersendiri. Prioritas penggunaan Dana Desa ditujukan untuk pembangunan sarana dasar dan pemberdayaan masyarakat desa.

Terbitnya Undang-Undang Nomor 6 Tahun 2014 Tentang Desa, memberikan mandat kepada pemerintah pusat untuk mengalokasikan Dana Desa dalam APBN dan menyalurkannya ke setiap rekening desa per periode penyaluran. Sebelum adanya penyaluran Dana Desa, setiap desa telah menerima Alokasi Dana Desa (ADD) dari pembagian dana perimbangan yang diterima pemerintah daerah kabupaten/kota. Besaran ADD kurang lebih 10 persen setelah dikurangi Dana Alokasi Khusus (DAK). Besaran ADD mengacu pada Peraturan Menteri Dalam Negeri Nomor 113 Tahun 2014 tentang Pengelolaan Desa. Dana Desa yang ditransfer ke setiap APB (Anggaran Pendapatan dan Belanja) Desa oleh pemerintah akan menjadi salah satu sumber pendapatan desa dalam APB Desa.

Gambar 1. Penyaluran Dana Desa 2015-2019

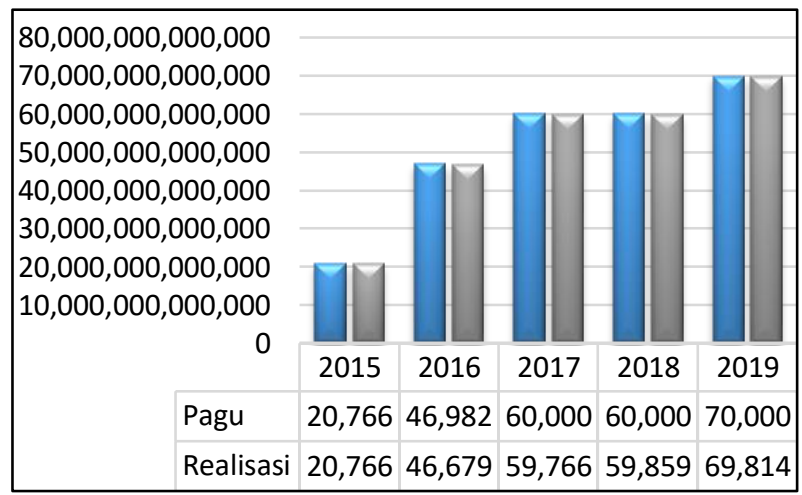

Sumber: LKPP 2015-2019

Data statistik pada Gambar 1 menunjukkan tren peningkatan jumlah anggaran dan realisasi penyaluran Dana Desa setiap tahunnya. Jumlah pagu Dana Desa di tahun 2019 mencapai Rp70 triliun atau meningkat 16,67 persen dari tahun sebelumnya. Setiap tahun hampir 100 persen Dana Desa berhasil disalurkan. Diharapkan dengan adanya penyaluran Dana Desa dapat meningkatan kesejahteraan masyarakat dan mengurangi ketimpangan antara pedesaan dan daerah tertinggal dengan perkotaan. 
Dari 514 kabupaten/kota yang ada, sejumlah 122 kabupaten ditetapkan sebagai kabupaten daerah tertinggal untuk periode 2015 s.d 2019 (Peraturan Presiden Nomor 131 Tahun 2015). Berdasarkan pasal 1 ayat 1 dalam Perpres (Peraturan Presiden ) tersebut, daerah tertinggal didefinisikan sebagai daerah kabupaten yang masyarakat dan wilayahnya relatif kurang berkembang dibanding daerah lain dalam skala nasional. Kabupaten dengan status daerah tertinggal ditetapkan per lima tahun (mengacu pada RPJMN).

\section{Gambar 2. Peta Persebaran Daerah Tertinggal}

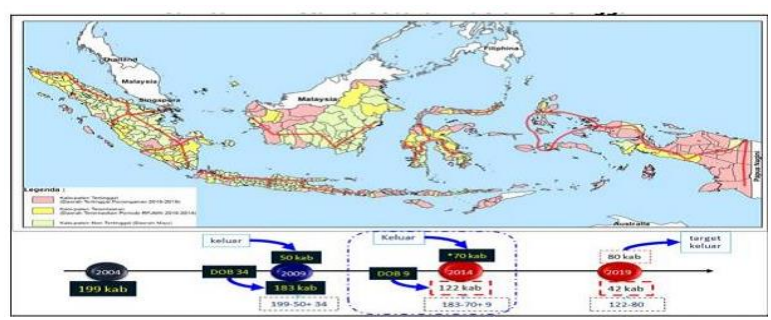

Sumber: Kemendes PDTT, 2016

Berdasarkan Gambar 2, dari 122 kabupaten daerah tertinggal, jumlah daerah tertinggal lebih dominan pada Kawasan Indonesia Tengah dan Kawasan Indonesia Timur. Jumlah kabupaten daerah tertinggal di kedua tersebut mencapai 103 kabupaten atau 84,42 persen (Bappenas 2016). Sebanyak 19 kabupaten atau 15,57 persen berada di Kawasan Indonesia Barat. Provinsi dengan jumlah kabupaten daerah tertinggal terbanyak ialah Provinsi Papua, dengan 26 kabupaten atau sebesar 89,66 persen dari total 29 kabupaten.

Gambar 3. Pertumbuhan Ekonomi Daerah Tertinggal 2014 dan 2015

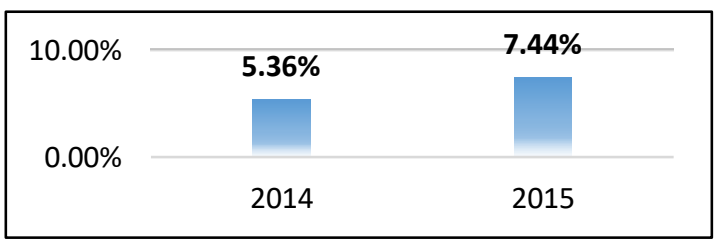

Sumber: Kemendes PDTT, 2015

Gambar 3 menunjukkan laju pertumbuhan ekonomi pada 122 kabupaten daerah tertinggal mengalami kenaikan signifikan dari 5,36 persen pada 2014 menjadi 7,44 persen pada tahun 2015 . Hal tersebut seiring dengan temuan Tangkumahat, et.al (2017) yang menunjukkan bahwa Dana Desa berpengaruh pada meningkatnya pendapatan masyarakat di Kecamatan Pineleng, Kabupaten Minahasa. Selain itu, hal tersebut juga berakibat pada penurunan tingkat kemiskinan sebagai dampak penerimaan Dana Desa di Kabupaten Tulungagung selama tahun 2015 dan 2016 (Sari \& Abdullah 2017).

Penelitian mengenai pengaruh penyaluran Dana Desa terhadap indikator perekonomian sudah banyak dilakukan, namun sebagian besar hanya dilakukan terbatas pada daerah tertentu dan waktu penelitian yang tidak cukup lama. Oleh karena itu, penelitian ini mengangkat judul, "Pengaruh Penyaluran Dana Desa Pada Indikator Perekonomian Kabupaten Daerah Tertinggal di Indonesia" untuk mengetahui pengaruh penyaluran Dana Desa terhadap dua indikator perekonomian pada 122 kabupaten daerah tertinggal dari periode tahun 2015 sampai dengan tahun 2018. Dua indikator yang diteliti yakni: (i) tingkat kemiskinan dan (ii) PDRB (Pendapatan Domestik Regional Bruto) per kapita.

\section{LANDASAN TEORI}

Daerah kabupaten yang tidak cukup berkembang, baik masyarakat dan wilayahnya, dibandingkan dengan kabupaten/kota lain dalam skala nasional dikategorikan sebagai daerah tertinggal. Smith (2012) dalam "Decentralization: The Territorial Dimension of The State", menggunakan istilah "keterbelakangan" untuk menganalogikan ketertinggalan. Keterbelakangan adalah suatu kondisi sulit untuk mengatur sumber pendapatan dalam memperkuat kemandirian fiskal di tingkat lokal.

Penetapan 122 kabupaten daerah tertinggal merupakan hasil lanjutan akumulasi perhitungan dari RPJMN 2010 s.d 2014. Dari 183 kabupaten daerah tertinggal, pemerintah telah menuntaska sebanyak 70 kabupaten melalui upaya percepatan pembangunan. Namun pada tahun 2013, terdapat pemekaran sembilan Daerah Otonom Baru yang ditambahkan langsung dalam daftar kabupaten daerah tertinggal.

Sebagaimana De Janvry \& Sadoulet (2010), transfer pendapatan berperan menaggulangi kemiskinan. Pemerintah sejak tahun 2015 telah mengambil kebijakan mengalokasikan Dana Desa untuk mendorong pembangunan desa-desa yang mengalami ketertinggalan pembangunan. Dalam Undang-Undang Desa pasal 72 menyebutkan bahwa alokasi Dana Desa yang diterima setiap kabupaten dihitung dan dialokasikan secara adil dan merata.

Berdasarkan PP 8 tahun 2016 tentang 8 tahun 2016 tentang Perubahan Kedua PP Nomor 60 Tahun 2014 tentang Dana Desa, Dana Desa dialokasikan berdasarkan 90 persen alokasi dasar yang sama untuk seluruh desa dan 10 persen formula, terdiri dari: jumlah penduduk desa, luas wilayah desa, angka kemiskinan desa, dan tingkat kesulitan geografis. Namun, untuk desa yang belum tersedia data jumlah penduduk, angka kemiskinan, dan luas wilayah dapat digunakan data desa induk secara proporsional. Sedangkan untuk data tingkat kesulitan geografis bersumber dari data pemerin- 
tah daerah. Rincian bobot alokasi formula adalah sebagai berikut:

a. Jumlah penduduk desa memiliki bobot 25 persen;

b. Jumlah penduduk miskin desa memiliki bobot 35 persen;

c. Luas wilayah desa memiliki bobot 10 persen;

d. Kesulitan geografis memiliki bobot 30 persen.

Berdasarkan PP Nomor 8 Tahun 2016, Dana Desa disalurkan secara bertahap pada tahun anggaran berjalan dengan ketentuan:

a. Tahap I pada bulan Maret sebesar 60 persen;

b. Tahap II pada bulan Agustus sebesar 40 persen;

\subsection{Indikator Perekonomian Penentuan Daerah Tertinggal}

Berdasarkan Perpres Nomor 131 Tahun 2015 Tentang Penetapan Daerah Tertinggal Tahun 2015 s.d 2019, penetapan kategori tertinggal pada suatu daerah didasarkan pada enam kriteria perhitungan, yaitu:

a. Perekonomian masyarakat;

b. Kualitas sumber daya manusia;

c. Ketersediaan infrastruktur

d. Kapasitas keuangan daerah;

e. Aksesibilitas;

f. Karakteristik daerah.

Untuk indikator perekonomian masyarakat, dibagi menjadi dua kriteria (Bappenas 2016), yaitu:

a. Tingkat kemiskinan yakni persentase jumlah penduduk miskin;

b. Pengeluaran/pendapatan penduduk per kapita (PDRB per kapita).

\subsection{Kemiskinan}

Kemiskinan adalah kondisi ketidakmampuan ekonomi untuk memenuhi standar hidup kebutuhan dasar sehari-hari (baik berupa pangan, sandang, maupun papan). Kondisi tersebut ditandai dengan rendahnya jumlah kemampuan pendapatan. Rendahnya kemampuan pendapatan juga berdampak pada kurangnya kemampuan memenuhi kebutuhan hidup lain seperti kesehatan dan pendidikan, baik untuk dirinya maupun anggota keluarganya (Nugroho 1995). Untuk mengukur kemiskinan, BPS (Badan Pusat Statistik) menggunakan pendekatan kemampuan memenuhi kebutuhan dasar (basic needs approach). Sumber data utama yang dipakai untuk mengukur kemiskinan adalah data dari Survei Sosial Ekonomi Nasional (Susenas).

\subsection{Konsep Produk Domestik Regional Bruto (PDRB)}

Indikator utama ekonomi untuk melihat laju pertumbuhan ekonomi tingkat daerah ialah PDRB. Menurut konsep dasar BPS, PDRB adalah penjumlahan seluruh nilai tambah bruto dari seluruh aktivitas unit ekonomi/usaha yang menghasilkan barang dan jasa, dalam suatu daerah pada periode tertentu, tanpa memperhatikan kepemilikan atas faktor produksi.

PDRB dapat disusun atas dasar harga berlaku ataupun atas dasar harga konstan. PDRB atas dasar harga berlaku menggambarkan nilai tambah barang dan jasa yang dihitung dengan menggunakan harga pada setiap tahun. Dari perhitungan tersebut dapat diketahui karakteristik struktur perekonomian suatu daerah, apakah daerah tersebut tergolong ke dalam kategori daerah industri, daerah pertanian atau daerah jasa. PDRB atas dasar harga berlaku juga menunjukkan seberapa besar kemampuan sumber daya ekonomi yang dihasilkan suatu wilayah dari waktu ke waktu. Sedangkan untuk PDRB atas dasar harga konstan menunjukkan nilai tambah barang dan jasa yang disusun berdasarkan harga pada tahun dasar guna mengukur pertumbuhan ekonomi.

Bila PDRB tersebut dibagi dengan jumlah penduduk di daerah tersebut pada tahun berjalan, maka akan dihasilkan pendapatan per kapita (PDRB per kapita) pada tahun berkenaan. PDRB per kapita atas dasar harga berlaku berguna untuk mengetahui nilai PDB dan PNB per satu orang penduduk. Sedangkan PDRB per kapita atas dasar harga konstan berguna untuk mengetahui pertumbuhan nyata ekonomi per kapita penduduk suatu negara.

\subsection{Penilitian Sebelumnya}

Hasil penelitian sebelumnya merupakan hal yang sangat bermanfaat untuk menjadi perbandingan dan acuan yang memberikan gambaran terhadap hasil-hasil penelitian terdahulu. Studi tentang kebijakan Dana Desa di Indonesia telah dilakukan oleh beberapa peneliti sebelumnya dengan berbagai penekanan yang berbeda-beda.

Sebagai contoh, dalam Disertasi Prasetyanto (2012) menunjukkan bahwa penyaluran ADD telah memberikan pengaruh terhadap terhadap peningkatan kinerja fiskal dan perekonomian daerah. Ditandai dengan peningkatan Pendapatan Asli Daerah (PAD) dan peningkatan total pengeluaran daerah. Selain itu, ADD berpengaruh pada peningkatan pertumbuhan ekonomi desa, peningkatan penyerapan tenaga kerja sektor pertanian, pengurangan jumlah penduduk miskin dan peningkatan PDRB sektor pertanian.

Studi Afrilianto (2017) menganalisis pengaruh ADD terhadap pertumbuhan ekonomi (laju PDRB) di Kabupaten Bogor. Variabel independen peningkat ekonomi, mencakup: ADD, jumlah angkatan kerja, dan Indeks Pembangunan Manusia (IPM). Hasil penelitian menyatakan bahwa faktor-faktor yang mempengaruhi peningkatan laju PDRB secara positif ialah Alokasi Dana Desa dan 
jumlah angkatan kerja. Sedangkan IPM berpengaruh negatif dan tidak signifikan terhadap PDRB. Tangkumahat, et. al (2017) menemukan bahwa Dana Desa memiliki pengaruh positif dalam peningkatan ekonomi yang ditandai dengan peningkatan pendapatan masyarakat di 14 desa di Kecamatan Pineleng Kabupaten Minahasa.

Sari \& Abdullah (2017) menganalisis dampak Dana Desa terhadap kemiskinan di 257 desa di Kabupaten Tulungagung. Hasil penelitian menyatakan bahwa Dana Desa berpengaruh negatif dan signifikan terhadap tingkat kemiskinan desa sehingga terjadi perbedaan tingkat kemiskinan desa pada tahun 2015 s.d 2016 di Kabupaten Tulungagung. Skripsi Kosasih (2018) menganalisis dampak Dana Desa terhadap lima indikator utama pembangunan ekonomi di Indonesia dengan menggunakan model persamaan simultan. Lima indikator tersebut terdiri dari: kemiskinan, ketimpangan, tenaga kerja, pertumbuhan ekonomi, dan inflasi. Hasilnya menunjukkan bahwa penyaluran Dana Desa telah memberikan dampak baik bagi lima indikator utama tersebut.

Badan Kebijakan Fiskal juga melakukan kajian evaluasi Dana Desa dengan judul Manfaat Dana Desa Dalam Percepatan Pembangunan dan Pengentasan Kemiskinan Desa (2017). Sejak Dana Desa diimplementasikan tahun 2015, tingkat kemiskinan perdesaan menurun dari 14,2 persen (tahun 2015) menjadi 13,9 persen (tahun 2017). Jumlah penduduk miskin perdesaan turun dari 17,94 juta jiwa (tahun 2015) menjadi 17,10 juta jiwa (tahun 2017). Seiring dengan membaiknya kinerja indikator kemiskinan desa dan ketimpangan antar desa tersebut, maka program Dana Desa dinilai memberikan manfaat positif dalam mengurangi kemiskinan dan ketimpangan di tingkat desa, walaupun signifikansi dampaknya belum dapat diukur dalam 3 tahun pelaksanaan Dana Desa.

\subsection{Kerangka Penelitian}

Mengacu pada latar belakang dan tujuan penelitian, secara skematis kerangka penelitian dapat dilihat pada gambar berikut:

Gambar 4 Kerangka Penelitian

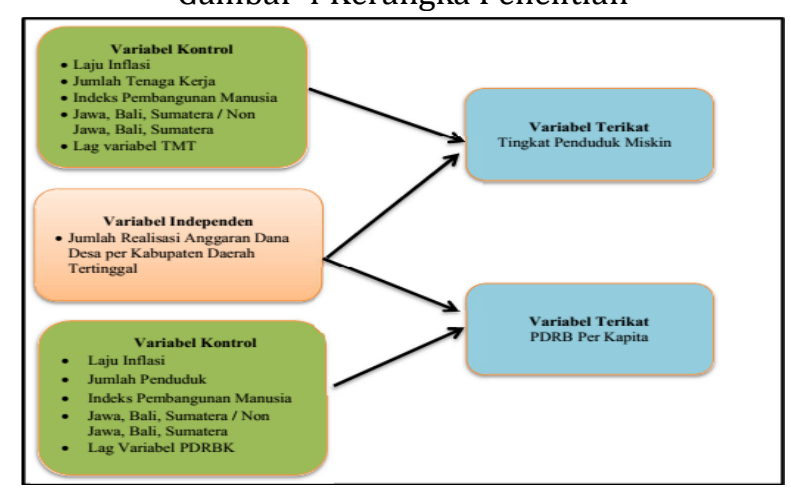

Sumber: Diolah oleh Penulis

\subsection{Hipotesis \\ a. Pengaruh Dana Desa terhadap tingkat kemiskinan}

Sari \& Abdullah (2017), menganalisis dampak Dana Desa terhadap kemiskinan desa di Kabupaten Tulungagung. Hasilnya menyatakan bahwa Dana Desa memiliki pengaruh negatif dan signifikan terhadap tingkat kemiskinan desa sehingga terjadi perbedaan tingkat kemiskinan desa pada tahun 2015 s.d 2016. Dalam pembahasannya dijelaskan bahwa tujuan penyaluran Dana Desa adalah untuk meningkatkan perekonomian dan kesejahteraan dan kualitas hidup masyarakat desa serta mengentaskan kemiskinan melalui pemenuhan infrastruktur dasar dan kebutuhan dasar masyarakat desa.

Menurut Azwardi \& Sukanto (2014), dengan adanya ADD, pemerintah desa dapat memberikan pelayanan yang lebih prima kepada masyarakat desa. Pemerintah desa juga dapat memberdayakan lebih banyak masyarakat desa dalam program dan kegiatan pembangunan desa. Program dan kegiatan pembangunan desa memiliki tiga fokus sasaran, yakni untuk menurunkan pengangguran, kemiskinan dan ketimpangan. Banyak faktor yang dapat mempengaruhi penurunan tingkat kemiskinan desa, yang salah satunya adalah Dana Desa. Berdasarkan uraian tersebut di atas, maka hipotesis pertama dalam penelitian ini adalah:

H1 : Realisasi Penyaluran Dana Desa memiliki hubungan asosiatif yang negatif terhadap Tingkat Kemiskinan.

\section{b. Pengaruh Dana Desa terhadap PDRB per kapita}

Studi mengenai pengaruh Alokasi Dana Desa terhadap pertumbuhan ekonomi dapat dilihat pada penelitian Afrilianto (2017). Dalam penelitian tersebut menyatakan bahwa faktor-faktor yang mempengaruhi peningkatan laju PDRB secara positif dan signifikan ialah ADD dan jumlah angkatan kerja. Salah satu fokus utama penggunaan Dana Desa adalah penyerapan tenaga kerja melalui penciptaan lapangan usaha baru. Ketika masyarakat memperoleh pekerjaan maka masyarakat akan memperoleh pendapatan. Kemudian Bempah (2013) menyatakan bahwa dari hasil tanggapan responden yang menyatakan terjadi peningkatan pendapatan pada responden masyarakat miskin setelah penerimaan ADD. Berdasarkan uraian diatas, hipotesis kedua dalam penelitian ini ialah:

H2: Realisasi Penyaluran Dana Desa memiliki hubungan asosiatif yang positif terhadap PDRB per Kapita. 


\section{METODOLOGI PENELITIAN}

\subsection{Jenis Penelitian}

Jenis penelitian yang digunakan adalah penelitian kuantitatif. Penelitian ini menggunakan serangkaian metode untuk menguji suatu teori dengan menganalisis hubungan antar variabel dalam penelitian dianalisis melalui prosedur statistik (Creswell 2014).

Dilihat dari model dan tingkat penjelasannya, penelitian ini dikategorikan sebagai penelitian asosiatif dengan model persamaan simultan. Penelitian asosiatif bertujuan untuk mengetahui hubungan atau pengaruh penyaluran Dana Desa terhadap dua indikator perekonomian daerah tertinggal. Model persamaan simultan merupakan model ekonometrik yang terdiri atas beberapa persamaan yang saling berhubungan sebagai satu sistem untuk menggambarkan indikasi hubungan timbal balik ekonomi antara tingkat kemiskinan dan tingkat PDRB per kapita sesuai yang diatur dalam Buku Petunjuk Pelaksanaan (Juklak) Identifikasi Masalah-masalah Ketertinggalan Kabupaten Daerah Tertinggal (2016). Estimasi regresi Ordinary Least Square tidak bisa digunakan dalam model persamaan simultan.

\subsection{Jenis dan Sumber Data}

Objek penelitian yang diteliti ialah penyaluran Dana Desa pada 122 kabupaten daerah tertinggal selama periode tahun 2015-2018. Tahun 2015 merupakan awal penyaluran Dana Desa yang bersumber dari APBN.

Penelitian ini menggunakan data sekunder yang diperoleh dari berbagai sumber. Beberapa data yang diperoleh dari BPS, baik di tingkat pusat, provinsi dan kabupaten, mencakup data jumlah penduduk miskin, PDRB per kapita atas dasar harga konstan (PDRBK ADHK), laju inflasi, jumlah tenaga kerja, angka IPM dan jumlah penduduk untuk setiap kabupaten daerah tertinggal. Sementara untuk data realisasi penyaluran Dana Desa diperoleh dari website Ditjen Perimbangan Keuangan berupa data realisasi Dana Desa per kabupaten tahun 2015-2016 dan Ditjen Perbendaharan berupa data realisasi penyaluran Dana Desa oleh KPPN tahun 2017-2018. Untuk semua data tersebut tidak dilakukan pembedaan hingga tingkatan level desa dan kelurahan.

Penggunaan beberapa variabel kontrol ditujukan untuk membantu memperkuat hubungan variabel dependen dengan variabel independen, memperbaiki model penelitian dan menghindari residual yang cukup besar. Penggunaan beberapa variabel kontrol dalam penelitian ini mengacu pada beberapa hasil penelitian terkait tingkat kemiskinan dan PDRB. Selain itu, penggunaan variabel inflasi, jumlah tenaga kerja, IPM pada model tingkat kemiskinan juga diperhitungkan, karena dianggap memberikan pengaruh pada peningkatan pendapatan masyarakat yang selanjutnya mempengaruhi tingkat kemiskinan. Sedangkan Penggunaan variabel inflasi, jumlah penduduk dan IPM pada model PDRBK, karena memberikan pengaruh pada besaran PDRBK.

Variabel IPM masih menjadi acuan outcome pembangunan, terlebih telah diformalkan sebagai salah satu indikator utama capaian belanja. PDRB dan populasi adalah variabel agregat yg sulit dipisahkan tanpa dasar teori yang kuat. Pendorong PDRB tidak hanya dari kelompok penduduk miskin, namun juga dari kelompok penduduk yang lain. Selain itu, kontribusi kelompok penduduk miskin sebagai tenaga kerja dlm populasi relatif sangat kecil. Dalam penelitian ini juga ditambahkan satu variabel dummy yakni area Jawa, Bali dan Sumatera. Selain itu dalam model penelitian ini digunakan lag variabel ( $\mathrm{t}-1)$ atas 2 variabel terikat. Apabila tidak menggunakan variabel lag, pengaruh perubahan terhadap estimasi model bisa sangat drastis, karena efek tahun sebelumnya tidak dimasukkan.

\subsection{Model Penelitian}

Berdasarkan landasan teori, hipotesis yang dirancang, dan variabel-variabel penelitian yang telah dijelaskan sebelumnya, model penelitian dibagi ke dalam dua persamaan struktural, yakni: model persamaan tingkat kemiskinan dan model persamaan PDRB per Kapita. Maka dari itu, model penelitian yang diusulkan yakni:

a. Tingkat kemiskinan

$$
\begin{array}{rl}
T M T_{i t}=\alpha_{0}+\beta_{1} J & R A D D_{i t}+\beta_{2} I N F_{i t} \\
& +\beta_{3} P D R B K_{i t}+\beta_{4} T K_{i t} \\
& +\beta_{5} I P M_{i t} \\
& +\beta_{6} J B S_{i t}+\beta_{7} T M T_{i(t-1)}+\varepsilon_{i t}
\end{array}
$$

Keterangan:

TMT = Tingkat Kemiskinan (Persentase)

$\mathrm{t} \quad=$ tahun 2015-2018

JRADD = Jumlah Realisasi Anggaran Dana Desa

INF = Laju Inflasi

PDRBK = PDRB Per Kapita

TK = Jumlah Tenaga Kerja

IPM = Indeks Pembangunan Manusia

JBS = Jawa, Bali, Sumatera (0), Non Jawa, Bali, Sumatera (1)

$\operatorname{TMT}_{(\mathrm{t}-1)}=$ Lag variabel Tingkat Kemiskinan

b. Indikator PDRB per kapita

$$
\begin{aligned}
P D R B K_{i t}=\alpha_{0}+ & \beta_{1} J R A D D_{i t}+\beta_{2} T M T_{i t} \\
& +\beta_{3} P O P_{i t}+\beta_{4} I N F_{i t} \\
& +\beta_{5} I P M_{i t}+\beta_{6} J B S_{i t} \\
& +\beta_{7} P D R B K_{i(t-1)}+\varepsilon_{i t}
\end{aligned}
$$

Keterangan:

PDRBK = PDRB Per Kapita

$\begin{array}{ll}\mathrm{t} & =\text { tahun 2015-2018 } \\ \text { JRADD } & =\text { Jumlah Realisasi Anggaran Dana Desa } \\ \text { TMT } & =\text { Tingkat Kemiskinan (Persentase) }\end{array}$ 
POP = Jumlah Penduduk

INF = Laju Inflasi

IPM = Indeks Pembangunan Manusia

JBS = Jawa, Bali, Sumatera (0), Non Jawa, Bali, Sumatera (1)

$\operatorname{PDRBK}_{(\mathrm{t}-1)}=$ Lag variabel PDRB Per Kapita

\subsection{Definisi Operasional}

Jumlah Realisasi Anggaran Dana Desa (JRADD) merupakan realisasi anggaran Dana Desa yang telah disalurkan ke 122 kabupaten daerah tertinggal setiap tahunnya, mulai dari tahun 20152018.

Tingkat Kemiskinan adalah persentase jumlah penduduk yang rata-rata pengeluaran per kapita per bulannya di bawah angka garis kemiskinan pada 122 kabupaten daerah tertinggal.

PDRB per Kapita adalah PDRB atas dasar harga konstan (PDRB ADHK) untuk setiap 122 kabupaten daerah tertinggal yang dibagi dengan jumlah penduduk setiap kabupaten pertahunnya, dimulai dari periode 2015-2018

\subsection{Metode Analisis Data}

Alat analisis yang digunakan untuk menguji hipotesis dalam penelitian ini yakni:

\section{a. Analisis statistik deskriptif}

Analisis statistik deskriptif digunakan untuk menggambarkan dan meringkas data sebelum melakukan analisis inferensial. Analisis ini juga berguna untuk mendeskripsikan data menjadi analisis informasi berbentuk tabel dan grafik. Analisis statistik deskriptif dilakukan untuk mengetahui gambaran mengenai penyaluran Dana Desa dan dua indikator perekonomian di 122 kabupaten daerah tertinggal selama periode analisis.

b. Analisis Inferensial,

Analisis Inferensial digunakan untuk menganalisis pengaruh Dana Desa terhadap dua indikator perekonomian pada 122 kabupaten daerah tertinggal serta variabel-variabel yang mempengaruhinya dalam model persamaan simultan. Adapun lima tahapan analisis Inferensial dapat dilihat pada Gambar 5.

Gambar 5. Tahapan Analisis Inferensial

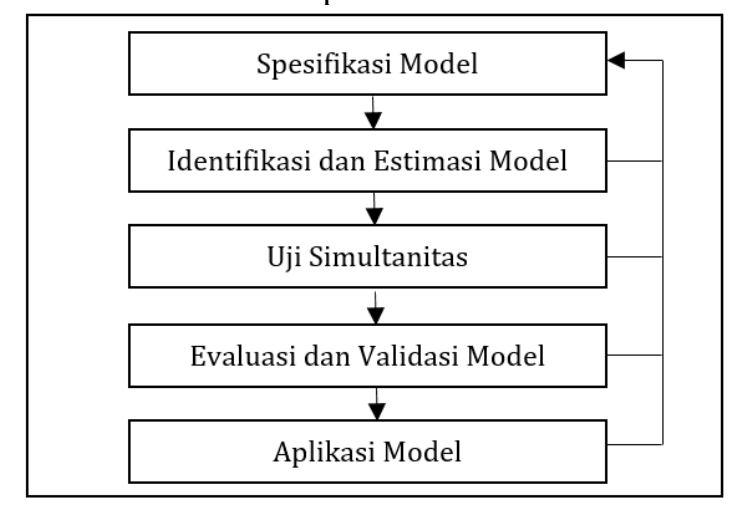

Sumber: Diolah oleh Penulis
Tahap pertama dalam analisis inferensial adalah spesifikasi model. Tahap spesifikasi model dimulai dengan menyusun model persamaan simultan dengan menggunakan variabel yang relevan dan hipotesis tanda yang telah ditentukan. Kedua, terhadap model persamaan simultan yang telah disusun, dilakukan proses identifikasi untuk mengetahui metode estimasi apa yang tepat digunakan pada model. Ketiga, terhadap model yang telah diestimasi, dilakukan pengujian simultanitas untuk mengetahui apakah model memiliki masalah simultanitas atau tidak. Jika model telah sesuai maka dilakukan evaluasi dan validasi. Terhadap model penelitian dilakukan uji normalitas dan 3 uji asumsi regresi linier klasik untuk mendeteksi penyimpangan dan membuat penanggulangan atas penyimpangan terjadi. Tahapan yang terakhir ialah melakukan uji signifikansi parameter dan uji koefisien determinasi. Jika terdapat masalah pada identifikasi, estimasi, uji simultanitas, ataupun aplikasi model maka selanjutnya dilakukan respesifikasi terhadap model penelitian.

c. Uji simultanitas

Uji simultanitas merupakan tahapan selanjutnya untuk menentukan apakah model memiliki masalah simultanitas atau tidak. Pengujian simultanitas dilakukan dengan hausman spesification test.

d. Uji normalitas dan asumsi klasik (evaluasi dan validasi model)

Ghozali (2016) dan Gujarati (2010), langkah awal yang harus dilakukan dalam analisis regresi adalah membentuk model taksiran atau persamaan yang akan digunakan untuk masalah peramalan. Asumsi-asumsi yang harus dipenuhi tersebut akan dideteksi, dibahas beserta konsekuensi penyimpangan, serta penanggulangan yang harus dilakukan jika terjadi penyimpangan. Setidaknya ada uji normalitas dan tiga uji asumsi regresi linier klasik yang akan dilakukan pada setiap model penelitian, yakni:

1) Uji heterosidiksitas

Uji heterosidiksitas dilakukan untuk mengetahui apakah dalam model terjadi ketidaksamaan varians dari residual. Hasil yang diharapkan adalah varians gangguan bersifat konstan atau memiliki sifat homoskedastik (Ghozali 2016).

2) Uji multikolinieritas

Salah satu asumsi yang harus dipenuhi dalam uji asumsi klasik adalah tidak ada multikolinearitas di antara variabel-variabel prediktor yang terlibat dalam model regresi (tidak terjadi multikolinieritas antar variabel penjelas Xi). 
3) Uji autokorelasi

Uji autokorelasi dilakukan untuk mengetahui apakah dalam model terdapat korelasi antara kesalahan pengganggu pada periode $t$ dengan kesalahan pengganggu pada periode $\mathrm{t}-1$ dan untuk menilai hubungan otomatis antar error atau error dengan periode waktu (Ghozali 2016). Ketika terdapat masalah autokorelasi, model tidak bisa dipakai untuk periode berikutnya. Uji autokorelasi dilakukan dengan melihat nilai statistik Durbin-Watson, dengan lima kriteria pengujian, yakni:

a) Jika $0<\mathrm{d}<\mathrm{dL}$, maka terjadi autokorelasi positif.

b) Jika $\mathrm{dL}<\mathrm{d}<\mathrm{dU}$, maka terjadi keraguraguan ada atau tidaknya autokorelasi.

c) Jika 4-dL< d $<$, maka terjadi autokorelasi negatif.

d) Jika 4-dU $<$ d $<4$-dL, maka terjadi keraguraguan ada atau tidaknya autokorelasi.

e) Jika $d u<d<4$-du, maka tidak terjadi autokorelasi baik positif atau negatif.

4) Uji normalitas

Uji normalitas dilakukan untuk mengetahui apakah sampel penelitian yang dipilih telah memenuhi kriteria sebaran distribusi normal (Ghozali 2016).

e. Uji signifikansi parameter dan koefisien determinasi (aplikasi model)

Uji signifikansi parameter bertujuan untuk mengetahui ada atau tidaknya hubungan parameter di dalam model regresi. Uji signifikansi parameter bisa dilakukan secara simultan maupun parsial.

1) Uji signifikansi simultan

Uji signifikansi simultan dilakukan untuk mengetahui apakah variabel independen secara simultan berpengaruh signifikan terhadap variabel dependen (Nachrowi 2008). Uji ini sering dinamakan Uji statistik F. Hasil uji statistik F dapat ditentukan dengan melihat nilai $\operatorname{Prob}(F$-statistic $)$ pada model kemudian dibandingkan dengan $\alpha$ $(0,10)$ untuk mengidentifikasi pengaruh tersebut. Jika nilai Prob(F-statistic $)<\alpha$, maka H0 ditolak atau berlaku sebaliknya. Hipotesis pada uji statistik F, yakni:

H0 = Variabel independen dan variabel kontrol secara simultan tidak berpengaruh signifikan terhadap variabel dependen.

$\mathrm{H} 1$ = Variabel independen dan variabel kontrol secara simultan berpengaruh signifikan terhadap variabel dependen.

2) Uji signifikansi parsial

Uji signifikansi parsial (uji statistik t) dilakukan untuk mengetahui variabel independen mana yang memiliki pengaruh signifikan terhadap variabel dependen secara individual. Tanda positif (+) dan negatif (-) yang ada di awal nilai koefisien regresi merupakan rujukan arah dari pengaruh variabel independen terhadap variabel dependennya. Pengujian menggunakan tingkatan signifikansi $\alpha=0,10$. Terdapat dua kriteria untuk pengujian hipotesis, yakni:

a) Bila nilai signifikansi $\mathrm{t} \leq$ 0,10 maka H0 ditolak, artinya terdapat pengaruh parsial yang signifikan antara satu variabel independen terhadap variabel dependen secara.

b) Bila nilai signifikansi $t>0,10$ maka $\mathrm{HO}$ diterima, artinya tidak terdapat pengaruh parsial yang signifikan antara satu variabel independen terhadap variabel dependen.

3) Uji koefisien determinasi ( $\left.R^{2}\right)$

Nilai hasil uji koefisien determinasi menggambarkan besarnya pengaruh dari variabel dependen dalam menjelaskan variasi variabel independen (Ghozali 2016). Nilai koefisien determinasi berada di antara 0 dan 1 , jika nilai $R$ squared besar (mendekati satu) menunjukkan bahwa variabel independen dalam model mampu menjelaskan hampir seluruh informasi yang diperlukan dalam memprediksi pengaruh variabel dependen.

\section{HASIL PENELITIAN}

\subsection{Deskripsi Data Penelitian}

\subsubsection{Gambaran Umum Kewilayahan Daerah Tertinggal}

Dari 122 kabupaten daerah tertinggal, penyebaran lebih banyak di Kawasan Indonesia Tengah dan Kawasan Indonesia Timur. Jika dibagi kedalam enam zona, maka pembagian porsi kabupaten daerah tertinggal dan jumlah desa penerima Dana Desa per zona yang dijabarkan pada Tabel 1 .

Tabel 1. Zona Kabupaten dan Desa di Kabupaten Daerah Tertinggal

\begin{tabular}{|c|c|c|c|}
\hline No & Zona & $\begin{array}{c}\text { Jumlah } \\
\text { Kabupaten }\end{array}$ & $\begin{array}{c}\text { Jumlah } \\
\text { Desa }\end{array}$ \\
\hline 1 & Sumatera & 13 & 1.760 \\
\hline 2 & Jawa \& Bali & 6 & 1.460 \\
\hline 3 & Nusa Tenggara & 26 & 3.557 \\
\hline 4 & Kalimantan & 12 & 2.197 \\
\hline 5 & Sulawesi & 18 & 2.377 \\
\hline 6 & Maluku \& Papua & 47 & 7.973 \\
\hline & Total & 122 & 19.324 \\
\hline
\end{tabular}

Sumber: Diolah dari data BPS

Berdasarkan Tabel 1 dapat dilihat zona Maluku dan Papua memiliki jumlah kabupaten daerah tertinggal terbanyak dengan 47 kabupaten, disusul oleh zona Nusa Tenggara dengan jumlah kabupaten daerah tertinggal sebanyak 26 kabupaten. Zona Sulawesi, Sumatera dan Kalimantan berada di urutan selanjutnya dengan masing-masing jumlah kabupaten daerah tertinggal sebanyak 18, 13 dan 12 kabupaten. Zona Jawa dan Bali merupakan zona dengan jumlah 
kabupaten daerah tertinggal terendah dengan 6 kabupaten.

Gambar 6. Jumlah Desa di Daerah Tertinggal Menurut Zona

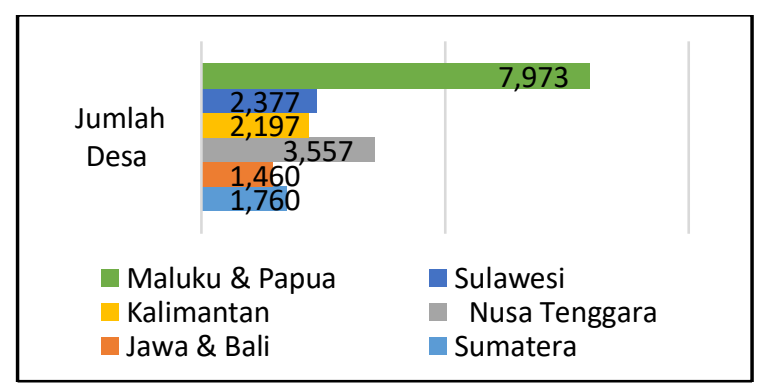

Sumber: Diolah dari data BPS

Dari Gambar 6, zona Maluku dan Papua memiliki jumlah desa penerima Dana Desa terbanyak, yakni 7.973 desa, disusul oleh zona Nusa Tenggara dengan 3.557 desa penerima Dana Desa. Walaupun zona Sumatera lebih banyak jumlah kabupaten daerah tertinggal dibandingkan zona Kalimantan, tetapi untuk jumlah desa penerima Dana Desa di zona Kalimantan lebih banyak dengan jumlah 2.197 desa dibandingkan dengan zona Sumatera sebanyak 1.760 desa. Zona Jawa dan Bali merupakan zona dengan jumlah desa penerima dana desa terendah, yakni sebanyak 1.460 desa.

Tabel 2. Lima Kabupaten dengan Jumlah Desa Penerima Dana Desa Terbanyak

\begin{tabular}{|c|c|c|c|c|}
\hline No & Kabupaten & Provinsi & $\begin{array}{c}\text { Jumlah } \\
\text { Desa }\end{array}$ & $\begin{array}{c}\text { Persentase } \\
\text { Desa }\end{array}$ \\
\hline 1 & Tolikara & Papua & 541 & $2,80 \%$ \\
\hline 2 & Yahukimo & Papua & 510 & $2,64 \%$ \\
\hline 3 & Nias Selatan & Sumatera Utara & 459 & $2,38 \%$ \\
\hline 4 & Sintang & $\begin{array}{c}\text { Kalimantan } \\
\text { Barat }\end{array}$ & 390 & $2,02 \%$ \\
\hline 5 & Lanny Jaya & Papua & 354 & $1,83 \%$ \\
\hline
\end{tabular}

Sumber: Diolah dari data BPS

Berdasarkan Tabel 2, diketahui bahwa lima kabupaten dengan jumlah desa penerima Dana Desa terbanyak. Kabupaten Tolikara merupakan kabupaten dengan jumlah desa penerima Dana Desa terbanyak, yakni sebanyak 541 desa atau 2,80 persen dari jumlah total desa penerima Dana Desa di 122 kabupaten daerah tertinggal.

\subsubsection{Tingkat Kemiskinan}

Kemiskinan yang tinggi mengindikasikan belum tercapainya kesejahteraan masyarakat di suatu negara. Secara umum, jumlah penduduk miskin di 122 kabupaten daerah tertinggal mengalami penurunan setiap tahunnya dengan akumulasi penurunan tingkat kemiskinan dari periode 2015 s.d 2018 sebanyak 4,43 persen atau berkurang sebanyak 223.593 jiwa. Tren penurunan kemiskinan dapat dilihat pada Gambar 7.
Gambar 7. Jumlah Penduduk Miskin di 122 Kabupaten Daerah Tertinggal

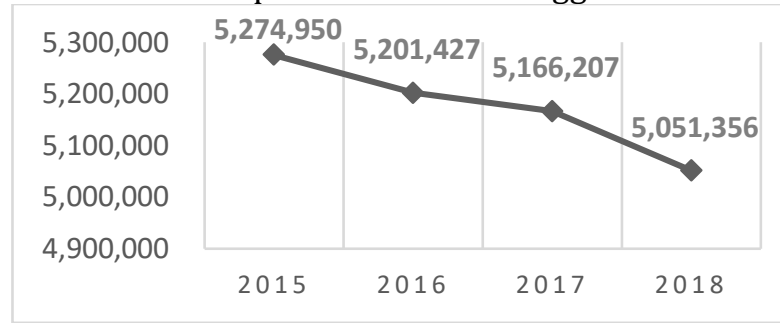

Sumber: Diolah dari data BPS

Tabel 3. Jumlah Penduduk Miskin Per Zona

\begin{tabular}{|c|c|c|c|c|c|}
\hline Zona & $\mathbf{2 0 1 5}$ & $\mathbf{2 0 1 6}$ & $\mathbf{2 0 1 7}$ & $\mathbf{2 0 1 8}$ & Akumulasi \\
\hline Sumatera & 8,30 & 8,28 & 8,24 & 8,10 & $0,20 \%$ \\
\hline Jawa \& Bali & 17,30 & 16,63 & 16,65 & 16,08 & $1,21 \%$ \\
\hline $\begin{array}{c}\text { Nusa } \\
\text { Tenggara }\end{array}$ & 34,01 & 33,91 & 33,91 & 33,44 & $0,57 \%$ \\
\hline Kalimantan & 5,85 & 5,84 & 5,98 & 6,20 & $-0,34 \%$ \\
\hline Sulawesi & 11,16 & 11,30 & 11,37 & 11,49 & $-0,33 \%$ \\
\hline $\begin{array}{c}\text { Maluku \& } \\
\text { Papua }\end{array}$ & 23,38 & 24,03 & 23,86 & 24,69 & $-1,31 \%$ \\
\hline Total & 100 & 100 & 100 & 100 & $4,43 \%$ \\
\hline
\end{tabular}

Sumber: Diolah dari data BPS

Berdasarkan Tabel 3 untuk kabupaten daerah tertinggal di zona Sumatera, zona Jawa dan Bali dan zona Nusa Tenggara selama periode 2015 s.d 2018 berhasil menurunkan jumlah penduduk miskin. Sedangkan kabupaten daerah tertinggal di zona Kalimantan, Sulawesi, Maluku dan Papua jumlah penduduk miskin selama periode 2015 s.d 2018 mengalami fluktuasi.

Tabel 4. Lima Kabupaten dengan Penurunan Jumlah Penduduk Miskin Terbanyak

\begin{tabular}{|c|c|c|c|c|}
\hline No & Kabupaten & Provinsi & $\begin{array}{c}\text { Penurunan } \\
\text { Jumlah } \\
\text { Penduduk } \\
\text { Miskin }\end{array}$ & $\begin{array}{c}\text { Persentase } \\
\text { Penurunan } \\
\text { Penduduk } \\
\text { Miskin }\end{array}$ \\
\hline 1 & Sampang & Jawa Timur & 35.530 & $14,78 \%$ \\
\hline 2 & $\begin{array}{c}\text { Lombok } \\
\text { Timur }\end{array}$ & NTB & 25.320 & $11,40 \%$ \\
\hline 3 & Bangkalan & Jawa Timur & 24.900 & $11,52 \%$ \\
\hline 4 & $\begin{array}{c}\text { Lombok } \\
\text { Tengah }\end{array}$ & NTB & 17.938 & $12,13 \%$ \\
\hline 5 & Lebak & Banten & 17.610 & $13,93 \%$ \\
\hline
\end{tabular}

Sumber: Diolah dari data BPS

Berdasarkan data selama periode 2015 s.d 2018, Kabupaten Sampang merupakan kabupaten daerah teringgal yang berhasil menurunkan jumlah penduduk miskin tertinggi yakni sebanyak 35.530 jiwa atau 14,78 persen. Selanjutnya diikuti empat kabupaten yang lain, yakni Kabupaten Lombok Timur, Kabupaten Bangkalan, Kabupaten Lombok Tengah dan Kabupaten Lebak (Tabel 4).

Terdapat beberapa kabupaten daerah tertinggal berhasil menurunkan jumlah penduduk miskin, dan terdapat lima kabupaten yang belum berhasil menurunkan jumlah penduduk miskin atau terjadi penambahan jumlah penduduk miskin selama periode 2015 s.d 2018. Pada Kabupaten Kupang terjadi penambahan jumlah penduduk 
miskin sebanyak 7.690 jiwa atau 9,50 persen, dibandingkan tahun 2015.

Tabel 5. Lima Kabupaten dengan Penambahan Jumlah Penduduk Miskin

\begin{tabular}{|c|c|c|c|c|}
\hline No & Kabupaten & Provinsi & $\begin{array}{c}\text { Penambahan } \\
\text { Jumlah } \\
\text { Penduduk } \\
\text { Miskin }\end{array}$ & $\begin{array}{c}\text { Persentase } \\
\text { Penambahan } \\
\text { Penduduk } \\
\text { Miskin }\end{array}$ \\
\hline 1 & Kupang & NTT & 7.690 & $9,50 \%$ \\
\hline 2 & Sintang & $\begin{array}{c}\text { Kalimantan } \\
\text { Barat }\end{array}$ & 5.820 & $15,80 \%$ \\
\hline 3 & Nduga & Papua & 3.760 & $11,26 \%$ \\
\hline 4 & Nunukan & $\begin{array}{c}\text { Kalimantan } \\
\text { Utara }\end{array}$ & 3.540 & $35,98 \%$ \\
\hline 5 & Paniai & Papua & 3.110 & $5,07 \%$ \\
\hline
\end{tabular}

Sumber: Diolah dari data BPS

\subsubsection{PDRB Per Kapita}

Dalam penelitian ini, PDRB akan dibagi dengan jumlah penduduk yang disebut pendapatan PDRB per kapita (PDRBK). Secara umum, PDRBK pada 122 kabupaten daerah tertinggal mengalami pertumbuhan setiap tahunnya, dengan akumulasi pertumbuhan dari periode 2015 s.d 2018 sebanyak 10,66 persen atau secara keseluruhan meningkat sebanyak Rp.282.781.826,00. Zona Maluku dan Papua merupakan zona dengan peningkatan pertumbuhan PDRBK tertinggi, seperti yang dijelaskan pada Gambar 8 dan Gambar 9.

Gambar 8. PDRB Per Kapita 122 Kabupaten Daerah Tertinggal

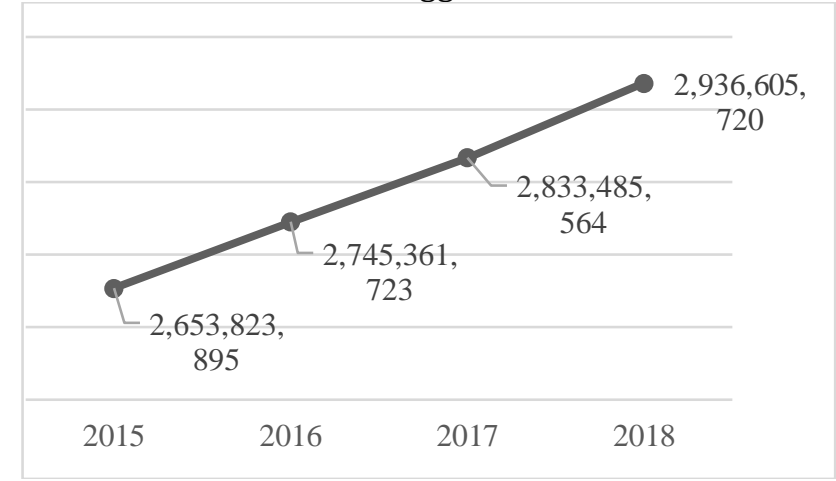

Sumber: Diolah dari data BPS

Gambar 9. Pertumbuhan PDRB Per Kapita Berdasarkan Zona

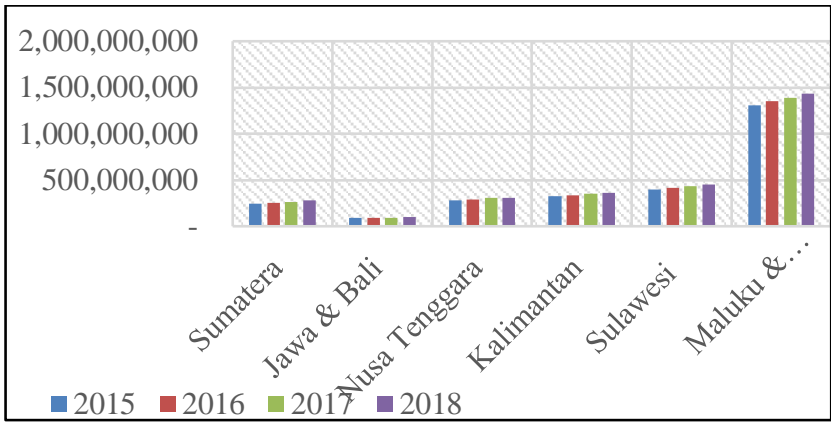

Sumber: Diolah dari data BPS

Berdasarkan Tabel 6, terdapat lima kabupaten daerah tertinggal dengan laju pertumbuhan PDRBK tertinggi, yang dihitung dari perbedaan PDRBK tahun 2015 terhadap PDRBK tahun 2018. Kabupaten Halmahera Selatan merupakan kabupaten dengan laju pertumbuhan PDRBK tertinggi dengan persentase 35 persen. Selanjutnya diikuti empat kabupaten lainnya yakni Kabupaten Nias Selatan, Kabupaten Lampung Barat, Kabupaten Jeneponto dan Kabupaten Banggai Laut. Selain itu, pada 121 kabupaten mengalami laju pertumbuhan PDRBK kecuali untuk Kabupaten Biak Numfor, yang PDRB Per Kapita tumbuh negatif sebesar -6 persen.

Tabel 6. Laju Pertumbuhan PDRB Per Kapita Kabupaten Daerah Tertinggal

\begin{tabular}{|c|c|c|c|}
\hline No & Kabupaten & Provinsi & Laju PDRBK \\
\hline 1 & $\begin{array}{c}\text { Halmahera } \\
\text { Selatan }\end{array}$ & Maluku Utara & $35 \%$ \\
\hline 2 & Nias Selatan & $\begin{array}{c}\text { Sumatera } \\
\text { Utara }\end{array}$ & $27 \%$ \\
\hline 3 & $\begin{array}{c}\text { Lampung } \\
\text { Barat }\end{array}$ & $\begin{array}{c}\text { Lampung } \\
\text { Sulawesi } \\
\text { Selatan }\end{array}$ & $22 \%$ \\
\hline 5 & Banggai Laut & $\begin{array}{c}\text { Sulawesi } \\
\text { Tengah }\end{array}$ & $22 \%$ \\
\hline 121 & Teluk Bintuni & Papua Barat & $3 \%$ \\
\hline 122 & Biak Numfor & Papua & $-6 \%$ \\
\hline
\end{tabular}

Sumber: Diolah dari data BPS

\subsubsection{Jumlah Realisasi Anggaran Dana Desa}

Gambar 10 menunjukkan total jumlah realisasi anggaran Dana Desa untuk 122 kabupaten daerah tertinggal meningkat setiap tahunnya. Tahun 2015, total jumlah realisasi anggaran Dana Desa sebesar Rp4.821.358.896.400,00 dan pada tahun 2018 dengan total jumlah realisasi anggaran Dana Desa sebesar Rp15.775.469.070.718,00. Jika dijabarkan per desa, di tahun 2015 rata-rata per desa mendapatkan sekitar Rp. 249.501.081,00. Sedangkan pada tahun 2018, rata-rata per desa mendapatkan sekitar Rp816.366.646,00. Sehingga secara total ataupun per desa, pada tahun 2018 jumlah realisasi anggaran Dana Desa meningkat 227 persen jika dibandingkan tahun 2015.

Gambar 10. Pertumbuhan Realisasi Dana Desa di Daerah Tertinggal

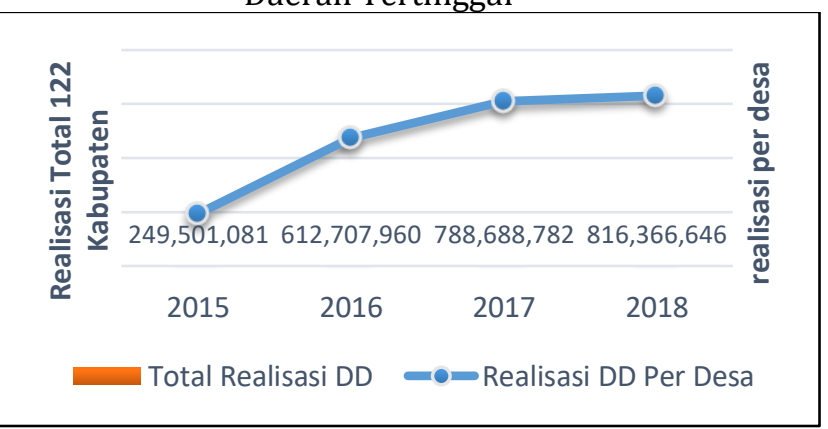

Sumber: Diolah dari data BPS

Tabel 7 menunjukkan bahwa setiap zona setiap tahunnya menerima jumlah realisasi anggaran Dana 
Desanya secara meningkat. Zona yang menerima peningkatan jumlah realisasi anggaran Dana Desa tertinggi dari 2015 s.d 2018 ialah zona Nusa Tenggara yakni meningkat sebesar 312 persen dari jumlah realisasi anggaran Dana Desa pada tahun 2015. Pada tahun 2015, rata-rata per desa di zona Nusa Tenggara mendapatkan sekitar Rp223.811.469,00, terendah dibandingkan zona yang lain. Namun di tahun 2018, rata-rata per desa di zona Nusa Tenggara mendapatkan penambahan sekitar Rp698.348.825,00. Zona Sulawesi merupakan zona dengan jumlah realisasi anggaran Dana Desa terendah dibandingkan zona yang lain, yakni hanya meningkat sebesar 187 persen atau bertambah sekitar Rp497.683.508,00 per desa. Jika dibandingkan antara jumlah realisasi anggaran Dana Desa tahun 2017 dan tahun 2018, zona Sulawesi dan zona Maluku \& Papua mengalami penurunan jumlah realisasi anggaran Dana Desa dibandingkan empat zona lainnya.

Tabel 7. Laju Pertumbuhan Realisasi Dana Desa Per

\begin{tabular}{|c|c|c|r|}
\hline \multirow{2}{*}{ Zonasi } & $\begin{array}{c}\text { Laju } \\
\text { Pertumbuhan } \\
\text { DD (2015 ke } \\
\mathbf{2 0 1 8 )}\end{array}$ & $\begin{array}{c}\text { ZD Per } \\
\text { Desa 2015 }\end{array}$ & $\begin{array}{c}\text { Laju } \\
\text { Pertumbuhan } \\
\text { DD Per Desa } \\
\text { (2015 ke 2018) }\end{array}$ \\
\hline Sumatera & $189 \%$ & 278.117 .650 & 525.295 .078 \\
\hline Jawa \& Bali & $190 \%$ & 290.907 .147 & 553.407 .373 \\
\hline $\begin{array}{c}\text { Nusa } \\
\text { Tenggara }\end{array}$ & $312 \%$ & 223.811 .469 & 698.348 .825 \\
\hline Kalimantan & $211 \%$ & 262.578 .595 & 553.184 .625 \\
\hline Sulawesi & $187 \%$ & 265.775 .917 & 497.683 .508 \\
\hline $\begin{array}{c}\text { Maluku \& } \\
\text { Papua }\end{array}$ & $228 \%$ & 238.607 .234 & 544.242 .943 \\
\hline
\end{tabular}

Sumber: Diolah dari data BPS

Tabel 8. Lima Kabupaten dengan Pertumbuhan Dana Desa per Desa Tertinggi

\begin{tabular}{|c|c|c|c|}
\hline No & Kabupaten & $\begin{array}{c}\text { Jumlah } \\
\text { Desa }\end{array}$ & $\begin{array}{c}\text { Laju } \\
\text { Pertumbuhan } \\
(2015 \text { ke 2018) }\end{array}$ \\
\hline 1 & Sumba Tengah & 65 & 2.582 .935 .292 \\
\hline 2 & Pasaman Barat & 19 & 1.426 .872 .053 \\
\hline 3 & Lombok Utara & 33 & 1.340 .223 .976 \\
\hline 4 & $\begin{array}{c}\text { Lombok } \\
\text { Tengah }\end{array}$ & 127 & 1.093 .697 .962 \\
\hline 5 & $\begin{array}{c}\text { Mamberamo } \\
\text { Tengah }\end{array}$ & 59 & 951.947 .519 \\
\hline
\end{tabular}

Sumber: Diolah dari data BPS

Tabel 8 menunjukkan bahwa dari 122 kabupaten daerah tertinggal terdapat lima kabupaten dengan laju pertumbuhan penerimaan realisasi dana desa tertinggi. Kabupaten Sumba Tengah, dengan jumlah desa sebanyak 65 desa, mendapatkan kucuran jumlah realisasi anggaran Dana Desa per desa pada tahun 2018 sebesar Rp2.871.330.015,00 atau meningkat sebanyak Rp2.582.935.292,00 dibandingkan jumlah realisasi anggaran Dana Desa di tahun 2015 sebesar Rp288.394.723,00. Dari lima kabupaten penerima realisasi dana desa tertinggi tiga kabupaten diantaranya masuk dalam zona Nusa Tenggara yakni Kabupaten Sumba Tengah, Kabupaten Lombok Utara dan Kabupaten Lombok Tengah. Satu kabupaten berasal dari zona Maluku dan Papua yakni Kabupaten Mambremo Tengah dan satu kabupaten berasal dari zona Sumatera yakni Kabupaten Pasaman Barat. Laju peningkatan ini telah sesuai dengan harapan pemerintah, dengan mengalokasikan Dana Desa yang diterima setiap desa sebesar Rp1-1,4 miliar dapat terpenuhi secara bertahap, sebagaimana pernyataan Presiden Joko Widodo (Kementerian Keuangan 2016).

Tabel 9. Lima Kabupaten dengan Pertumbuhan Dana Desa per Desa Terendah

\begin{tabular}{|c|c|c|c|}
\hline No & Kabupaten & $\begin{array}{c}\text { Jumlah } \\
\text { Desa }\end{array}$ & Laju Peningkatan \\
\hline 1 & Nias Selatan & 459 & 318.151 .301 \\
\hline 2 & Tolikara & 541 & 411.776 .885 \\
\hline 3 & Maybrat & 259 & 416.793 .181 \\
\hline 4 & $\begin{array}{c}\text { Halmahera } \\
\text { Barat }\end{array}$ & 170 & 419.557 .041 \\
\hline 5 & Lebak & 340 & 421.797 .271 \\
\hline
\end{tabular}

Sumber: Diolah dari data BPS

Tabel 9 menunjukkan bahwa dari 122 kabupaten daerah tertinggal terdapat lima kabupaten dengan laju pertumbuhan jumlah realisasi anggaran Dana Desa terendah. Kabupaten Nias Selatan, dengan total 459 desa, pada tahun 2018 hanya mendapat jumlah realisasi anggaran Dana Desa per desa sebesar Rp. 582.675.440,00 atau meningkat sebesar Rp. 318.151.301,00 sejak tahun 2015. Selain itu, pada lima kabupaten tersebut, jumlah realisasi anggaran Dana Desa pada tahun 2018 menurun jika dibandikan pada jumlah realisasi dana desa pada tahun 2017.

\subsection{Analisis Inferensia}

\subsubsection{Spesifikasi Model}

Pada model penelitian pengaruh penyaluran Dana Desa pada indikator perekonomian kabupaten daerah tertinggal terdapat dua persamaan struktural, yaitu: (i) Tingkat Kemiskinan dan (ii) PDRB per kapita. Dua model tersebut merupakan replikasi dari beberapa model penelitian sebelumnya terkait pengaruh Dana Desa terhadap perekonomian. Dalam penelitian ini beberapa variabel dikutip dari model persamaan simultan yang dipakai oleh penelitian Prasetyanto (2012) dan Kosasih (2018). Terdapat dua hal yang membedakan penelitian ini dengan penelitian sebelumnya. Pertama, dalam penelitian ini diberi penambahan variabel yakni IPM sebagai salah satu variabel dalam penelitian ini, seperti pada penelitian Afrilianto (2017). Kedua, dalam penelitian ini ditambahkan satu variabel dummy yakni area Jawa, Bali, dan Sumatera. 


\subsubsection{Identifikasi dan estimasi model}

Dalam penelitian Pengaruh Penyaluran Dana Desa pada Indikator Perekonomian Kabupaten Daerah Tertinggal di Indonesia ini terdiri dari dua persamaan struktural. Jumlah variabel endogen sama dengan jumlah persamaan dalam model yakni sebanyak dua variable: JMT dan PDRBK. Variabel predetermined di model persamaan tingkat kemiskinan sebanyak 6 variabel dan variabel predetermined di model persamaan PDRB per kapita, sebanyak 6 variabel.

Dengan komposisi variabel yang telah disebutkan, maka seluruh persamaan dalam model adalah over identified karena memenuhi kondisi $K-k>m-1$, dimana $\mathrm{K}$ adalah jumlah variabel predetermined dalam model dengan jumlah sebanyak 8 variabel. Sedangkan maksimal jumlah variabel predetermined dalam persamaan tertentu sebanyak 6 variabel dan jumlah variabel endogen (M) adalah 2. Dengan demikian, $K-k$ terkecil adalah 2 dan $m-1$ adalah 1 . Artinya, seluruh persamaan dalam model ini adalah over identified $(2>1)$. Persamaan dalam model teridentifikasi over identified, sehingga metode estimasi yang dapat digunakan ialah Two Stage Least Square (2SLS).

\subsubsection{Uji Simultanitas}

Pengujian ini merupakan tahapan selanjutnya untuk menentukan apakah model memiliki masalah simultanitas atau tidak. Pengujian simultanitas dapat dilakukan dengan hausman specification test. Berikut hasil pengujian hausman specification test setiap model penelitian seperti pada Tabel 10. Jika model memiliki masalah simultanitas, maka nilai $p$-value TMT residual $<10$ persen.

Tabel 10. Uji Simultanitas Dua Model

\begin{tabular}{|c|c|c|c|c|}
\hline Model & Variabel & Hipotesis & Prob. & Keputusan \\
\hline \multirow[t]{2}{*}{ TMT } & $\begin{array}{l}\text { PDRBK } \\
\text { CAP }\end{array}$ & \multirow{4}{*}{$\begin{array}{l}\mathrm{H}_{0}: \quad \text { Tidak } \\
\text { terdapat } \\
\text { masalah } \\
\text { simultanitas } \\
\mathrm{H}_{1}: \\
\text { Terdapat } \\
\text { masalah } \\
\text { simultanitas }\end{array}$} & 0.0921 & \multirow{2}{*}{$\begin{array}{l}\text { Terdapat } \\
\text { masalah } \\
\text { simultanitas }\end{array}$} \\
\hline & PDRBK_RES & & 0.0706 & \\
\hline \multirow[t]{2}{*}{ PDRBK } & TMT_CAP & & 0.0562 & \multirow{2}{*}{$\begin{array}{l}\text { Terdapat } \\
\text { masalah } \\
\text { simultanitas }\end{array}$} \\
\hline & TMT_RES & & 0.0520 & \\
\hline
\end{tabular}

Sumber: Diolah dari eviews 9

Terhadap dua model pada Tabel 10 tersebut perlu dilakukan estimasi dengan menggunakan simultaneously equation model karena terjadi masalah simultanitas. Estimasi 2SLS tepat digunakan untuk mengestimasi parameter dalam model.

\subsubsection{Uji normalitas dan asumsi klasik (evaluasi dan validasi model)}

Berikut hasil tiga uji asumsi regresi linier klasik dan uji normalitas dengan serangkaian treatment yang sesuai terhadap masalah tersebut.
Tabel 11. Ringkasan 3 Uji Asumsi Regresi Linier Klasik dan Uji Normalitas

\begin{tabular}{|c|c|c|c|c|}
\hline No & Pengujian & $\begin{array}{l}\text { Model } \\
\text { TMT }\end{array}$ & $\begin{array}{c}\text { Model } \\
\text { PDRBK }\end{array}$ & Treatment \\
\hline 1 & $\begin{array}{c}\text { Hetero- } \\
\text { skedastisitas }\end{array}$ & Ada & Ada & $\begin{array}{l}\text { Penggunaan metode } \\
\text { estimasi GLS Weight - } \\
\text { Cross section weight } \\
\text { sehingga varians akan } \\
\text { menjadi konstan } \\
\text { (Ghozali 2016). }\end{array}$ \\
\hline 2 & Autokorelasi & Ada & Ada & $\begin{array}{l}\text { Penggunaan } \begin{array}{l}\text { metode } \\
\text { estimasi }\end{array} \text { dengan } \\
\text { Coeficient } \\
\text { method - White Crosians } \\
\text { Section } \\
\text { (Ghozali 2016). }\end{array}$ \\
\hline 3 & $\begin{array}{c}\text { Multi- } \\
\text { kolineritas }\end{array}$ & $\begin{array}{l}\text { Tidak } \\
\text { Ada }\end{array}$ & $\begin{array}{l}\text { Tidak } \\
\text { Ada }\end{array}$ & $\begin{array}{lr}\begin{array}{l}\text { Tidak } \\
\text { treatment }\end{array} & \text { dilakukan } \\
\text { Koutsoyiannis } & \text { (1977), } \\
\text { pada model dengan } & \text { dengat } \\
\text { analisis data panel dapat } \\
\text { mengabaikan masalah } \\
\text { pelanggaran asumsi } \\
\text { multikolinearitas }\end{array}$ \\
\hline 4 & Normalitas & Ada & Ada & $\begin{array}{lr}\text { Dianggap } & \text { normal } \\
\text { berdasarkan } & \text { Central } \\
\text { Limit Theorem. } & \text { asumsi } \\
\text { normalitas } & \text { dapat } \\
\text { diabaikan untuk } & \text { kasus } \\
\text { ini karena model } & \text { memiliki jumlah sampel } \\
\text { yang besar (Ghozali } \\
\text { 2016) }\end{array}$ \\
\hline
\end{tabular}

Sumber: Hasil uji asumsi klasik dan uji normalitas

\subsubsection{Uji Hipotesis}

\section{Model tingkat kemiskinan}

Berikut hasil uji signifikansi parameter untuk model tingkat kemiskinan.

Tabel 12. Uji Signifikansi Parameter Model Tingkat Kemiskinan

\begin{tabular}{c}
\hline Prob(F-statistic) $=0.000000$ \\
$R$-squared overall $=0,999302$ \\
$R$-squared JRADD $=0,03459501$ \\
\hline
\end{tabular}

Sumber: Diolah dari eviews 9

1) Uji signifikansi simultan

Hasil tabel 12 menandakan bahwa variabel independen dan variabel kontrol dalam model penelitian secara simultan memiliki pengaruh signifikan terhadap variabel TMT.

2) Uji signifikansi parsial

Untuk mengetahui variabel independen mana yang memiliki pengaruh terhadap variabel dependen, maka dilanjutkan uji statistik t.

Tabel 13. Hasil Konversi Nilai Probabilitas Model Tingkat Kemiskinan

\begin{tabular}{|c|c|c|c|c|}
\hline Variabel & $\begin{array}{c}\text { Prob } \\
\text { uji } \boldsymbol{t}\end{array}$ & Koefisien & $\begin{array}{c}\text { Tanda } \\
\text { Koefisien }\end{array}$ & Signifikansi \\
\hline PDRBK & 0.0000 & $-8,97 \mathrm{E}-10$ & - & Signifikan** \\
\hline JRADD & 0.0459 & $-0,079803$ & - & Signifikan** \\
\hline INF & 0.0000 & 0,085393 & + & Signifikan** \\
\hline IPM & 0.1396 & $-0,023162$ & - & $\begin{array}{c}\text { Tidak } \\
\text { Signifikan }\end{array}$ \\
\hline JBS & 0.0000 & 0,203127 & + & Signifikan** \\
\hline TK & 0.0000 & $-1,94 \mathrm{E}-07$ & - & Signifikan** \\
\hline $\begin{array}{c}\text { LAG } \\
\text { TMT(t-1) }\end{array}$ & 0.0000 & 0,962971 & + & Signifikan** \\
\hline
\end{tabular}

Sumber: Diolah dari eviews 9 
Tabel 13 menunjukkan bawah terdapat variabel independen berupa JRADD serta variabel kontrol berupa PDRBK, INF, JBS, TK dan Lag TMT(t-1) yang memiliki nilai Prob uji $\mathrm{t}<\alpha(0,10)$. Hal ini menunjukkan bahwa kelima variabel tersebut secara individual merupakan variabel penjelas yang signifikan bagi variabel TMT. Berbeda halnya dengan variabel kontrol berupa IPM yang memiliki nilai Prob(F-statistic) $>\alpha(0,10)$ sehingga secara individual bukan merupakan penjelas signifikan bagi variabel TMT. Berikut model regresi matematis untuk model tingkat kemiskinan

$T M T_{i t}$

$=3,374709-0,079803 J R A D D_{i t}+0,085393 I N F_{i t}-8,97$

* $10^{-10}$ PDRBK $K_{i t}-0,000000194$ TK $_{i t}-0,023162$ IPM $_{i t}$

$+0,203127 J B S_{i t}+0,962971 T M T_{i(t-1)}+\varepsilon_{i t}$

3) Uji koefisien determinasi $\left(\mathrm{R}^{2}\right)$

Berdasarkan output pengujian pada Tabel IV.12, nilai koefisien determinasi atau $R$-squared overall yakni 0,999302. Nilai tersebut menggambarkan bahwa variabel independen dan kontrol yang digunakan dapat menjelaskan variasi dari variabel dependen dalam model penelitian sebesar 99,93 persen. Sedangkan sebesar 0,07 persen variasi variabel dependen TMT ditentukan variabel lain yang tidak diteliti dalam model penelitian. Sedangkan nilai dari $R$-squared parsial untuk variabel JRADD pada model tingkat kemiskinan ialah 3,50 persen yang menggambarkan besaran variasi variabel TMT yang ditentukan oleh JRADD.

\section{Model PDRB per kapita}

Berikut hasil uji signifikansi parameter untuk model PDRB per kapita

Tabel 14. Uji Signifikansi Parameter Model PDRB Per Kapita

\begin{tabular}{c} 
Prob(F-statistic) $=0.000000$ \\
$R$-squared overall $=0,999755$ \\
$R$-squared JRADD $=0.15463918$ \\
\hline
\end{tabular}

Sumber: Diolah dari eviews 9

1) Uji signifikansi simultan

Berdasarkan Tabel IV.14, variabel independen dan variabel kontrol dalam model penelitian secara simultan memiliki pengaruh signifikan terhadap variabel PDRBK.

2) Uji signifikansi parsial

Untuk mengetahui variabel independen mana yang memiliki pengaruh terhadap variabel dependen, maka dilanjutkan dengan uji statistik $t$.

Berdasarkan Tabel 15, terdapat variabel independen berupa JRADD serta variabel kontrol berupa TMT, INF, IPM, POP dan Lag PDRBK(t-1) yang memiliki nilai Prob uji $\mathrm{t}<\alpha(0,10)$ (tingkat signifikansi 10 persen), sehingga kelima variabel tersebut secara individual merupakan variabel penjelas yang signifikan bagi variabel dependen PDRBK. Untuk variabel kontrol berupa JBS yang memiliki nilai Prob(F-statistic) $>\alpha(0,10)$ sehingga secara individual bukan merupakan penjelas signifikan bagi variabel dependen PDRBK. Berikut model regresi matematis untuk model PDRB per kapita.

Tabel 15. Hasil Konversi Nilai Probabilitas Model PDRB Per Kapita

\begin{tabular}{|c|c|c|c|c|}
\hline Variabel & $\begin{array}{c}\text { Prob } \\
\text { uji } \boldsymbol{t}\end{array}$ & Koefisien & $\begin{array}{c}\text { Tanda } \\
\text { Koefisi } \\
\text { en }\end{array}$ & Signifikansi \\
\hline TMT & 0.0000 & $-10659,61$ & - & Signifikan** \\
\hline JRADD & 0.0038 & 125899,5 & + & Signifikan** \\
\hline IPM & 0.0000 & 5310,442 & + & Signifikan** \\
\hline INF & 0.0000 & 38266,36 & + & Signifikan** \\
\hline JBS & 0.1118 & $-45814,44$ & - & $\begin{array}{c}\text { Tidak } \\
\text { Signifikan }\end{array}$ \\
\hline POP & 0.0001 & $-0,259276$ & - & Signifikan** \\
\hline $\begin{array}{c}\text { LAG } \\
\text { PDRBK } \\
\text { (t-1) }\end{array}$ & 0.0000 & 1,020186 & + & Signifikan** \\
\hline
\end{tabular}

(Sumber: Diolah dari eviews 9)

$P D R B K_{i t}=-3.003 .663+$ $125.899,5 J R A D D_{i t}-10.659,61 T M T_{i t}-0,259276 P O P_{i t}+$ $38.266,36 I N F_{i t}+$

$5.310,44 I P M_{i t}-45.814,44 J B S_{i t}+$

$1,020186 P D R B K_{i(t-1)}+\varepsilon_{i t}$

3) Uji koefisien determinasi $\left(R^{2}\right)$

Berdasarkan output pengujian pada Tabel 14, nilai koefisien determinasi atau $R$-squared overall yakni 0,999755 . Nilai tersebut menggambarkan bahwa variabel independen dan kontrol yang digunakan dapat menjelaskan variasi dari variabel dependen dalam model penelitian sebesar 99,97 persen. Sedangkan sebesar 0,03 persen variasi variabel dependen PDRBK ditentukan variabel lain yang tidak diteliti dalam model penelitian. Sedangkan nilai dari $R$-squared parsial untuk variabel JRADD pada model PDRB per kapita ialah 15,35 persen. yang menggambarkan besaran variasi variabel PDRBK ditentukan JRADD.

\subsubsection{Pembahasan Hipotesis}

1. Pengaruh penyaluran dana desa terhadap tingkat kemiskinan

Berdasarkan hasil konversi nilai uji statistik t pada Tabel 13 dapat dilihat bahwa variabel JRADD serta variabel kontrol berupa PDRBK, INF, JBS, TK dan Lag TMT(t-1) memiliki nilai Prob uji $\mathrm{t}<\alpha$ $(0,10)$ atau berpengaruh signifikan terhadap variabel dependen TMT. Namun diantara variabelvariabel tersebut hanya JRADD, PDRBK dan TK yang berpengaruh negatif, dimana secara ekonomi arah tandanya sudah benar. Hal tersebut berarti peningkatan ketiga variabel tersebut akan berpengaruh signifikan terhadap penurunan tingkat kemiskinan pada 122 kabupaten daerah tertinggal selama 2015-2018. 
Berdasarkan hasil regresi model tingkat kemiskinan, dapat diketahui bahwa penyaluran Dana Desa memiliki pengaruh negatif terhadap tingkat kemiskinan dengan nilai koefisien $-0,079803$. Hasil tersebut menunjukan bahwa peningkatan realisasi penyaluran Dana Desa sebesar 1 persen akan akan menurunkan tingkat kemiskinan sebesar 0,00079803. Dengan demikian, hipotesis pertama (H1) dalam penelitian ini dapat diterima. Hasil tersebut sejalan dengan pernyataan Kemenkeu (2017) bahwa salah satu tujuan dari penyaluran Dana Desa adalah untuk mengentaskan kemiskinan.

Hasil penelitian ini juga sejalan dengan penelitian yang dilakukan oleh Sari dan Abdullah (2017) yang menyatakan bahwa Dana Desa memiliki pengaruh negatif dan signifikan terhadap tingkat kemiskinan desa. Terjadi perbedaan tingkat kemiskinan desa pada tahun 2015 s.d 2016 di Kabupaten Tulungagung.

Selain itu, variabel kontrol PDRBK dan TK juga memiliki pengaruh negatif dan signifikan terhadap turunnya tingkat kemiskinan di 122 kabupaten daerah tertinggal selama 2015-2018 dengan koefisien masing-masing sebesar $-0,000897$ dan -0,0000194. Berdasarkan uji simultanitas dan uji statistik $t$, variabel PDRBK merupakan variabel yang memiliki hubungan timbal balik dengan variabel TMT. Ini berarti jika PDRBK naik maka berpengaruh terhadap penurunan tingkat kemiskinan, yakni sebesar 0,0000000897. Jika variabel PDRBK dibuat dalam satuan juta, maka nilai koefisien tersebut adalah $-0,000897$ sehingga setiap kenaikan satu juta rupiah PDRBK akan menyebabkan penurunan TMT sebesar 0,000897. Untuk variabel TK, setiap penambahan satu orang tenaga kerja, tingkat kemiskinan akan turun sebesar 0,0000194. Hal tersebut menunjukkan bahwa pemanfaatan Dana Desa melalui swakelola masyarakat desa mampu meningkatkan jumlah tenaga kerja di 122 kabupaten daerah tertinggal, yang selanjutnya mampu meningkatkan pendapatan masyarakat.

Hasil penelitian ini sejalan dengan penelitian Prasetyanto (2012) yang menyatakan bahwa penyaluran alokasi Dana Desa telah memberikan arah yang benar untuk meningkatkan kinerja fiskal dan perekonomian daerah dengan mengurangi jumlah penduduk miskin.

\section{Pengaruh penyaluran dana desa terhadap PDRBK}

Berdasarkan hasil konversi nilai uji statistik t pada tabel 15 dapat dilihat bahwa variabel JRADD serta variabel kontrol berupa TMT, INF, IPM, POP dan Lag PDRBK (t-1) yang memiliki nilai Prob uji $\mathrm{t}<$ $\alpha(0,10)$ atau berpengaruh signifikan terhadap variabel dependen PDRBK. Namun diantara variabel-variabel tersebut hanya JRADD, INF, IPM dan Lag PDRBK (t-1) yang berpengaruh positif. Artinya peningkatan keempat variabel tersebut akan berpengaruh terhadap peningkatan PDRBK pada 122 kabupaten daerah tertinggal selama 2015-2018. Untuk variabel TMT dan POP memiliki pengaruh negatif dan signifikan terhadap penurunan PDRB per kapita di 122 kabupaten daerah tertinggal selama 2015-2018.

Berdasarkan hasil regresi pada model PDRBK dapat diketahui bahwa penyaluran Dana Desa memiliki pengaruh positif terhadap peningkatan PDRBK pada 122 kabupaten daerah tertinggal selama 2015 s.d 2018, dengan koefisien 125899,5. Hasil tersebut menunjukan bahwa peningkatan realisasi realisasi penyaluran Dana Desa sebesar 1 persen akan akan menyebabkan peningkatan PDRBK sebesar Rp1.258,99. Hasil ini berarti hipotesis kedua (H2) dalam penelitian ini dapat diterima.

Hasil penelitian ini sejalan dengan skripsi Afrilianto (2017) yang menyatakan bahwa faktorfaktor yang mempengaruhi peningkatan laju PDRB secara positif dan signifikan ialah ADD dan jumlah angkatan kerja. Salah satu fokus utama penggunaan Dana Desa adalah penyerapan tenaga kerja melalui penciptaan lapangan usaha baru. Ketika muncul lapangan usaha baru maka masyarakat akan memperoleh pendapatan.

Berdasarkan uji simultanitas dan uji statistik t, variabel TMT merupakan variabel yang memiliki hubungan timbal balik dengan variabel PDRBK. Sehingga jika tingkat kemiskinan naik satu persen maka berpengaruh terhadap penurunan PDRBK, yakni sebesar $-10.659,61$. Kenaikan tingkat kemiskinan menandakan naiknya tingkat pengangguran. Akibat dari hal tersebut, semakin banyak masyarakat yang tidak memiliki pendapatan.

Peningkatan penyaluran ADD juga mampu meningkatkan pertumbuhan ekonomi, meningkatkan penyerapan tenaga kerja sektor pertanian serta mampu menurunkan jumlah penduduk miskin di perdesaan. Pengaruh PDRB terhadap penurunan jumlah penduduk miskin dapat disebabkan karena ketika terjadi peningkatan pada pertumbuhan ekonomi, maka rata-rata pengeluaran perkapita juga akan meningkat. Peningkatan tersebut akan sejalan dengan penurunan kemiskinan (Nanga 2006).

\section{KESIMPULAN DAN SARAN}

\subsection{Kesimpulan}

Penelitian ini dilakukan untuk mengetahui pengaruh penyaluran Dana Desa terhadap dua indikator perekonomian pada 122 kabupaten daerah tertinggal selama periode tahun 2015 s.d tahun 2018. Berdasarkan penelitian yang telah 
dilakukan, simpulan penelitian yang didapat antara lain:

a. Dalam hasil penelitian ini menunjukkan bahwa penyaluran Dana Desa memiliki pengaruh negatif terhadap tingkat kemiskinan, sehingga dapat disimpulkan bahwa hipotesis pertama pada penelitian ini dapat diterima. Hal ini ditunjukkan dengan nilai koefisien JRADD yang bernilai negatif.

b. Selanjutnya dalam hasil penelitian menunjukkan bahwa penyaluran Dana Desa memiliki pengaruh positif terhadap PDRBK sehingga dapat disimpulkan hipotesis kedua pada penelitian ini dapat diterima. Hal ini ditunjukkan dengan nilai koefisien JRADD yang bernilai positif.

c. Berdasarkan uji simultan, terdapat masalah simultanitas atau hubungan timbal balik antara variabel TMT dan PDRBK. Jika PDRBK naik maka berpengaruh terhadap penurunan tingkat kemiskinan, ataupun sebaliknya.

\subsection{Saran}

Berkenaan dengan hasil pengujian dan kesimpulan di atas, berikut rekomendasi yang diusulkan:

a. Pemerintah daerah pada kabupaten daerah tertinggal diminta untuk lebih fokus dalam penggunaan realisasi Dana Desa yang telah disalurkan. Mengingat penyaluran Dana Desa merupakan kebijakan masih masih cukup baru yang dijalankan oleh pemerintah. Walaupun terbilang baru, program Dana Desa memiliki besaran alokasi anggaran yang tinggi dan setiap tahun besarannya terus meningkat.

b. Pemerintah pusat perlu melakukan sinergi ke semua unit hingga ke pemerintah desa melalui pembinaan dan pengawasan berkelanjutan atas penggunaan Dana Desa yang telah disalurkan.

c. Permasalahan mendasar di desa dan daerah tertinggal ialah tidak tersedianya dan/atau rendahnya kualitas infrastruktur dasar public dan kesulitan mendapatkan akses pelayanan dasar yang layak. Akibatnya akan berdampak pada rendahnya kualitas sumber daya manusia dan lemahnya perekonomian di daerah tersebut. Maka dari itu penggunaan Dana Desa diprioritaskan untuk pembangunan infrastruktur dasar dan pembinaan masyarakat desa agar kualitas sumber daya manusia pada kabupaten daerah tertinggal dapat meningkat. Selain itu fokus utama penggunaan Dana Desa adalah penyerapan tenaga kerja melalui penciptaan lapangan kerja baru. Semakin banyak lapangan kerja baru di desa, maka pendapatan masyarakat desa akan meningkat sehingga masyarakat lebih sejahtera dan tingkat kemiskinan akan berkurang. Tujuan akhirnya ialah semakin banyak kabupaten daerah tertinggal akan keluar dari klasifikasi daerah tertinggal.

d. Pemerintah pusat perlu mengkaji formulasi pengalokasian dan penyaluran Dana Desa pada 122 kabupaten daerah tertinggal agar lebih merata dan sesuai kebutuhan masingmasing kabupaten daerah tertinggal. Jika dibandingkan antara realisasi penyaluran Dana Desa pada tahun 2017 dan tahun 2018, beberapa kabupaten di zona Maluku dan Papua justru mengalami penurunan penerimaan realisasi penyaluran Dana Desa dibandingkan lima zona lainnya. Padahal jumlah kabupaten daerah tertinggal terbanyak ada di zona tersebut. Oleh karena itu, penyaluran Dana Desa perlu dikombinasikan dengan penataan dan pemetaan wilayah desa dan daerah tertinggal agar Dana Desa dapat disalurkan tepat sasaran.

e. Besaran proporsi anggaran Dana Desa yang diharapkan oleh Presiden Joko Widodo sebesar Rp1-1,4 miliar atau masih belum sesuai harapan. Sampai tahun 2018, secara rata-rata perdesa pada 103 kabupaten daerah tertinggal masih mendapat anggaran Dana Desa dibawah Rp1-1,4 miliar. Diusulkan pada masa mendatang agar formulasi perhitungan anggaran Dana Desa yang lebih baik pada 103 kabupaten daerah tertinggal, agar bisa memenuhi besaran angka harapan tersebut. Sehingga nantinya memberikan efek multiplier yang lebih besar pada dua indikator perkenomian di 122 kabupaten daerah tertinggal.

f. Perlu penyempurnaan sistem dan prosedur penyaluran Dana Desa yang lebih cepat, tepat dan sesuai kebutuhan. Diharapkan setiap desa sesegera mungkin dapat menerima penyaluran tersebut, sehingga desa juga bisa langsung menggunakannya untuk kepentingan penyelenggaraan kegiatan desa.

g. Penelitian tentang dampak Dana Desa terhadap indikator perekonomian daerah tertinggal di Indonesia perlu dilanjutkan dengan menambahkan series data agar estimasi dapat memperhatikan efek dari waktu yang ada. Diharapkan nantinya dapat memberikan masukan yang lebih komprehensif terhadap penyaluran Dana Desa dalam upaya menurunkan tingkat kemiskinan, meningkatkan PDRB per kapita dan mengentaskan daerah tertinggal di Indonesia.

\section{IMPLIKASI DAN KETERBATASAN}

\subsection{Implikasi Penelitian}

Implikasi penelitian dari aspek praktis diharapkan dapat memberikan manfaat bagi 
pembuat kebjakan mulai dari Kementerian Keuangan c.q. DJPK dan DJPb, Kementerian Desa, Pembangunan Daerah Tertinggal Dan Transmigrasi, Kementerian Dalam Negeri serta Pemerintah Daerah khususnya Kabupaten Daerah Tertinggal, dalam ranah implementasi kebijakan dan penyaluran Dana Desa terutama terkait perannya dalam mengatasi kemiskinan dan meningkatkan PDRB per Kapita di daerah tertinggal di Indonesia.

\subsection{Keterbatasan}

Dalam penelitian ini terdapat keterbatasanketerbatasan, diantaranya:

a. Jangka waktu periode penelitian yang digunakan ialah empat tahun, yakni dimulai dari tahun 2015-2018. Penggunaan periode penelitian yang berbeda mungkin akan menghasilkan simpulan penelitian yang berbeda.

b. Sampel penelitian sebanyak 243 observasi dengan 122 kabupaten daerah tertinggal selama 4 tahun berdasarkan purposive sampling yang bersifat subjektif. Dalam objek penelitian ini, untuk semua data tidak dilakukan pembedaan hingga tingkatan level desa dan kelurahan. Hasil berbeda dari penelitian ini dapat terjadi jika menggunakan teknik pengambilan sampel lain.

c. Penelitian ini dilakukan untuk menangkap fenomena pengaruh penyaluran Dana Desa pada dua indikator perekonomian pada 122 kabupaten daerah tertinggal. Penelitian ini tidak mengakomodasi untuk menangkap fenomena pengaruh penyaluran Dana Desa terhadap indikator perekonomian yang lebih spesifik untuk satu pemerintah daerah atau diluar dari 122 kabupaten daerah tertinggal. Selain itu penelitian ini ditujukan untuk menggambarkan indikasi hubungan timbal balik ekonomi antara tingkat kemiskinan dan tingkat PDRB per kapita.

d. Dana Desa sendiri merupakan salah satu bagian dalam dana transfer dalam APBD kabupaten, sehingga hanya menggambarkan sebagian kecil pengaruh pada perbaikan dua indikator perekonomian kabupaten daerah tertinggal.

\section{DAFTAR PUSTAKA}

Afrilianto, A.G. (2017). Analisis Dampak Alokasi Dana Desa Terhadap Pertumbuhan Ekonomi Di Kabupaten Bogor. Skripsi. Bogor: Institut Pertanian Bogor.

Azwardi, \& Suntoko. (2014). Efektifitas Alokasi Dana Desa (ADD) dan Kemiskinan di Provinsi Sumatera Selatan. Jurnal Ekonomi Pembangunan: 29-41.
Badan Pusat Statistik. (2020). Jumlah Penduduk 122 Kabupaten Daerah Tertinggal 2015-2018. Jakarta: BPS.

Badan Pusat Statistik. (2020). Persentase Penduduk Miskin Kabupaten 122 Kabupaten Daerah Tertinggal 2015-2018. Jakarta: BPS.

Badan Pusat Statistik. (2020). Produk Domestik Regional Bruto 122 Kabupaten Daerah Tertinggal 2015-2018. Jakarta: BPS.

Badan Pusat Statistik. (2020). Inflasi 2015-2019 122 Kabupaten Daerah Tertinggal 2015-2018. Jakarta: BPS.

Badan Pusat Statistik. (2020). Jumlah Tenaga Kerja 122 Kabupaten Daerah Tertinggal 2015-2018. Jakarta: BPS.

Badan Pusat Statistik. (2020). Indeks Pembangunan Manusia 122 Kabupaten Daerah Tertinggal 2015-2018. Jakarta: BPS.

Badan Pusat Statistik. (2020). Berita Resmi Statistik No. 09/01/Th. XXIII, 15 Januari 2020. Badan Pusat Statistik. 2020.

Badan Kebijakan Fiskal. (2017). Manfaat Dana Desa Dalam Percepatan Pembangunan dan Pengentasan Kemiskinan Desa. Jakarta: Kementerian Keuangan.

Bempah, R. (2013). Analisis Alokasi Dana Desa Dalam Meningkatkan Pendapatan. E-Jurnal Katalogis 1, no. 2 (April 2013).

Creswell, J.W. (2014). Research Design: Qualitative, Quantitative and Mixed Methods Approaches (4th ed.). Thousand Oaks, CA: Sage

Direktorat Jenderal Perimbangan Keuangan. (2017). Data Penyaluran Dana Desa 20152016. Jakarta: Kementerian Keuangan.

Direktorat Jenderal Perbendaharaan. (2020). Data Penyaluran Dana Desa 2017-2019. Jakarta: Kementerian Keuangan.

Ghozali, I. (2016). Aplikasi Analisis Multivariate dengan Program IBM SPSS 23. Semarang: Badan Penerbit Universitas Diponegoro.

Ghozali, S.M.A. (2019). Pengaruh Dana Desa dan Alokasi Dana Desa Terhadap Tingkat Kemiskinan Di Kecamatan Sendang Agung dalam Perspektif Ekonomi Islam. Skripsi. Lampung: Universitas Islam Negeri Raden Intan Lampung.

Gujarati, D. (2010). Basic Econometrics. Fifth Edition. New York: Mc Graw Hill.

Gulo, K.et al. (2017). Dampak alokasi belanja langsung terhadap ketimpangan ekonomi wilayah (Studi kasus Provinsi Sumatera Utara, Provinsi Jambi, dan Provinsi Bengkulu). Jurnal Paradigma Ekonomika 12, no. 2 (Juli - 
Desember 2017).

Kementerian Perencanaan Pembangunan Nasional. (2016). Laporan Akhir Koordinasi Strategis Percepatan Pelaksanaan Program Pembangunan Daerah Tertinggal untuk Mendukung PP No.78 Tahun 2014 dan Perpres No. 131 Tahun 2015. Jakarta: Kementerian PPN.

Kementerian Perencanaan Pembangunan Nasional. (2017). Buku Evaluasi Paruh Waktu RPJMN 2015-2019. Jakarta: Kementerian PPN.

Kementerian Keuangan. Peraturan Menteri Keuangan Nomor 93/PMK.07/2015 tentang Tata Cara Pengalokasian, Penyaluran, Penggunaan, Pemantauan, dan Evaluasi Dana Desa.

Kementerian Keuangan. Peraturan Menteri Keuangan Republik Indonesia Nomor 205/PMK.07/2019 Tentang Pengelolaan Dana Desa.

Kementerian Desa, Pembangunan Daerah Tertinggal, dan Transmigrasi. (2016). Buku Petunjuk Pelaksanaan (Juklak) Identifikasi Masalah-masalah Ketertinggalan Kabupaten Daerah Tertinggal. Jakarta: Kementerian Desa, Pembangunan Daerah Tertinggal, dan Transmigrasi.

Kementerian Desa, Pembangunan Daerah Tertinggal, dan Transmigrasi. (2020). Profil 122 Daerah Teringgal. Jakarta: Kementerian Desa, Pembangunan Daerah Tertinggal, dan Transmigrasi.

Kosasih, A. (2018). Dampak Dana Desa Terhadap Indikator Utama Pembangunan Ekonomi di Indonesia. Skripsi. Jakarta: Sekolah Tinggi Ilmu Statistik.

Koutsoyiannis, A. (1977). Theory of Econometrics: an Introductory Exposition of Econometric Methods, 2nd ed. London: MacMillan Press, Ltd.

Muslihah, S., Siregar, H.O., \& Sriniyati. (2019). Dampak Alokasi Dana Desa Terhadap Pembangunan Dan Kesejahteraan Masyarakat Desa Di Kabupaten Bantul Daerah Istimewa Yogyakarta. Jurnal Akuntansi, Ekonomi dan Manajemen Bisnis 7, no. 1 (Juli 2019): 85-93.

Nachrowi, D., \& Usman, H. (2006). Pendekatan populer dan praktis ekonometrika untuk analisis ekonomi dan keuangan. Jakarta: Lembaga Penerbit Fakultas Ekonomi Universitas Indonesia.

Nangarumba, M. (2008). Dampak Transfer Fiskal terhadap Kemiskinan di Indonesia: Suatu Analisis Simulasi Kebijakan. Disertasi. Bogor: Sekolah Pascasarjana, Institut Pertanian
Bogor.

Nugroho, H. (1995). Kemiskinan, Ketimpangan dan Kesenjangan. Yogyakarta: Aditya Media.

Oates, W.E. (1999). An Essay on Fiscal Federalism. Journal of Economic Literature, 37(3) (September 1999): 1120-49.

Prasetyanto, E. (2012). Dampak Alokasi Dana Desa pada Era Desesntralisasi Fiskal Terhadap Perekonomian Daerah di Indonesia. Disertasi. Bogor: Institut Pertanian Bogor.

Pemerintah Republik Indonesia. (2014). UndangUndang Nomor 6 Tahun 2014 tentang Desa.

Pemerintah Republik Indonesia. (2014). Peraturan Pemerintah Nomor 60 Tahun 2014 tentang Dana Desa bersumber dari APBN.

Pemerintah Republik Indonesia. (2014). Peraturan Pemerintah Republik Indonesia Nomor 78 Tahun 2014 Tentang Percepatan Pembangunan Daerah Tertinggal.

Pemerintah Republik Indonesia. (2014). Peraturan Pemerintah Republik Indonesia Nomor 8 tahun 2016 tentang 8 tahun 2016 tentang Perubahan Kedua PP Nomor 60 Tahun 2014 tentang Dana Desa

Pemerintah Republik Indonesia. (2015). Peraturan Presiden Nomor 2 Tahun 2015 tentang Rencana Pembangunan Jangka Menengah Nasional Tahun 2015 - 2019

Pemerintah Republik Indonesia. (2015). Peraturan Presiden Republik Indonesia Nomor 131 Tahun 2015 Tentang Penetapan Daerah Tertinggal Tahun 2015-2019.

Pemerintah Republik Indonesia. (2014). Peraturan Menteri Dalam Negeri Nomor 113 Tahun 2014 tentang Pengelolaan Desa.

Pemerintah Republik Indonesia. (2014). Peraturan Menteri Dalam Negeri Nomor 114 Tahun 2014 tentang Pembangunan Desa.

Pemerintah Republik Indonesia. (2018). Peraturan Menteri Dalam Negeri Republik Indonesia Nomor 20 Tahun 2018 tentang Pengelolaan Keuangan Desa.

Pemerintah Republik Indonesia. (2014). Peraturan Pemerintah Nomor 22 Tahun 2015 tentang Perubahan Atas Peraturan Pemerintah Nomor 60 Tahun 2014 tentang Dana Desa yang Bersumber dari Anggaran Pendapatan dan Belanja Negara.

Pemerintah Republik Indonesia. (2015). Peraturan Menteri Desa, Pembangunan Daerah Tertinggal, dan Transmigrasi Nomor 5 Tahun 2015 tentang Prioritas Penggunaan Dana Desa. 


\section{4}

Pemerintah Republik Indonesia. (2015). Peraturan Menteri Desa dan PDTT Nomor 21 Tahun 2015 tentang Prioritas Penggunaan Dana Desa Tahun 2016.

Pemerintah Republik Indonesia. (2015). Peraturan Menteri Desa, Pembangunan Daerah Tertinggal, dan Transmigrasi Nomor 3 tahun 2015 tentang Pendampingan Desa.

Sari, I.M., \& Abdullah, M.F. (2017). Analisis Ekonomi Kebijakan Dana Desa terhadap Kemiskinan Desa di Kabupaten Tulungagung. Jurnal Ekonomi Pembangunan, 15 (1).

Sekaran, U. \& Bougie, R. (2016). Research Methods for Business : Seventh Edition. United Kingdom: John Wiley \& Sons.

Smith, B.C. (2012). Decentralization: The Territorial Dimension of The State. Jakarta: Masyarakat Pemerintahan Indonesia.

Sugiyono. (2016). Metode Penelitian Bisnis (Pendekatan Kuantitatif, Kualitatif, dan R\&D. Bandung: Alfabeta.

Tangkumahat, F. V., Panelewen, V. V. J., \& Mirah, A. D. P. (2017). Dampak Program Dana Desa Terahdap Peningkatan Pembangunan dan Ekonomi di Kecamatan Pineleng Kabupaten Minahasa. Jurnal Agri-Sosio Ekonomi 13 (2A): 335-342.

Todaro, M.P., \& Smith, S.C. (2006). Economic Development Ninth Edition. United Kingdom: Pearson Education Limited.

Usman. (2006). Dampak Desentralisasi Fiskal terhadap Distribusi Pendapatan dan Tingkat Kemiskinan. Tesis Magister Sains. Program Pascasarjana, Institut Pertanian Bogor, Bogor.

World Bank. (2000). Global Poverty Report. Washington, DC: World Bank. 